\title{
DEMOKRACJA I KAPITALIZM: TEORIA POLITYCZNA ELLEN MEIKSINS WOOD
}

\author{
ELIASZ ROBAKIEWICZ
}

\begin{abstract}
Abstrakt: Ellen Meiksins Wood jest teoretyczką łączoną, wraz z Robertem Brennerem, z nurtem zwanym „politycznym marksizmem”. W niniejszym artykule postaram się przybliżyć, czym wyróżnia się ten nurt. W pierwszej części przedstawiam krótką charakterystykę „marksizmu politycznego” jako nurtu, w którym centrum zainteresowań stanowia stosunki reprodukcji społeczeństwa kapitalistycznego, oraz rekonstrukcję sporu o przejście od feudalizmu do kapitalizmu, czyli sporu o genezę tego społeczeństwa. Jednocześnie staram się wskazać, jak debata dotycząca problemu powstania kapitalizmu stanowi kluczowe zagadnienie, wokół rozwiązania którego zogniskowane zostały badania teoretyczki. W części drugiej omawiam to, w jaki sposób Meiksins Wood rozumie pojęcie „klasy”, a także jej badania dotyczące demokracji w antycznej Grecji.
\end{abstract}

Słowa kluczowe: Meiksins Wood, marksizm polityczny, Brenner, kapitalizm, feudalizm 


\section{Wstęp}

Ellen Meiksins Wood ${ }^{1}$ - choć żadna z jej prac nie doczekała się jeszcze tłumaczenia na język polski - jest w anglosaskim świecie akademickim badaczką uznaną i szeroko rozpoznawalną ma na koncie dziewięć książek oraz niezliczoną liczbę artykułów naukowych ${ }^{3}$. Przez dwie dekady (do końca lat dziewięćdziesiątych) wykładała nauki polityczne w Glendon College w York University w Kanadzie. Jako redaktorka współpracowała m.in. z tak cenionymi pismami, jak New Left Review oraz Monthly Review (Patriquin 2012, 238-243). Podstawowe pole jej badań stanowiła historia oraz jej znaczenie dla szerzej pojętej teorii marksistowskiej. Wraz z innym amerykańskim historykiem, Robertem Brennerem, sformułowała perspektywę teoretyczną, którą określono mianem „marksizmu politycznego”4 (Meiksins Wood 2016). Projekt marksizmu politycznego uznać można za próbę odnowy „materializmu historycznego” jako metody badawczej, która łącząc takie dyscypliny jak historia, teoria polityczna, ekonomia polityczna, socjologia czy filozofia stawia w centrum analizy stosunki klasowe oraz historyczny proces przemian sposobów produkcji i relacji własności.

W niniejszym artykule postaram się przybliżyć specyfikę tego nurtu, śledząc przede wszystkim spór o specyfikę kapitalizmu jako określonego sposobu produkcji. W centrum moich rozważań znajdzie się zatem debata dotycząca przejścia od feudalizmu do kapitalizmu oraz szerzej relacji kapitalizmu i niekapitalistycznych form organizacji pracy i życia społecznego.

Twórczość Meiksins Wood można podzielić na trzy kategorie ${ }^{5}$ : artykuły publicystyczne, prace historyczne oraz polemiczne książki teoretyczne. Od początku swej kariery akademickiej w latach siedemdziesiątych aż po lata dziewięćdziesiąte pisała głównie artykuły. Są to z jednej strony artykuły naukowe, przede wszystkim z zakresu historii teorii politycznej antyku

\footnotetext{
${ }^{1}$ Ellen Meiksins Wood zmarła w 14.01.2016; pożegnalny esej Viveka Chibbera na jej temat można przeczytać w magazynie Jacobin pod adresem: https://www.jacobinmag.com/2016/01/ellen-Meiksins Wood-obituarychibber-retreat-from-class-origins-of-capitalism-marxist/ (Chibber 2016) oraz w Socialist Review autorstwa Alexa Callinicosa pod adresem: http://socialistreview.org.uk/410/marxism-loses-passionate-champion (Callinicos 2016).

2 Wydany w serii wydawniczej „Historical Materialism” przewodnik (reader) autorstwa Larry’ego Patriquina stanowi dobre oraz dość obszerne wprowadzenie do jej twórczości (Patriquin 2012).

3 Jedyne szersze opracowanie poglądów Meiksins Wood w języku polskim znajduje się w książce Filipa Ilkowskiego Imperializm kapitalistyczny we współczesnych ujęciach teoretycznych, choć dotyczy ono w największej mierze teorii imperializmu Meiksins Wood zawartej przede wszystkim w książce Empire of Capital (Ilkowski 2015, 307324) (Meiksins Wood 2003).

${ }^{4}$ W jednym z wywiadów Meiksins Wood wyjaśnia, że określenie „marksizm polityczny” zostało użyte po raz pierwszy przez Guya Bois w odniesieniu do teorii Roberta Brennera jako pejoratywne określenie podejścia teoretycznego, które kładzie zbyt duży nacisk na stosunki społeczne, a zbyt mały na rolę „sposobu produkcji”. Meiksins Wood broniąc „marksizmu politycznego” stwierdza, że jedną z podstawowych przesłanek tego podejścia teoretycznego jest wyjaśnianie, w jaki sposób ekonomiczne stosunki są jednocześnie relacjami społecznymi (Meiksins Wood 2013).
}

${ }^{5}$ Pełna anglojęzyczna chronologicznie ułożona bibliografia Ellen Meiksins Wood w: (Patriquin: 311-315). 
i nowożytności, oraz interwencje w aktualne debaty teoretyczne, dotyczące zwłaszcza teorii historii, a z drugiej „przekłady” na bardziej ogólny i zrozumiały język w postaci szeregu artykułów publicystycznych dla takich periodyków jak The Socialist Register, Monthly Review czy New Left Review

\section{Marksizm polityczny}

W części pierwszej artykułu przedstawię w oparciu o historyczne przykłady specyfikę i węzłowe zagadnienia analiz amerykańskiej teoretyczki. W tym celu zarysuję jej najważniejsze tezy na temat historycznych korzeni angielskiego kapitalizmu jako sposobu produkcji, zestawiając je jednocześnie z opisem sytuacji w Republice Zjednoczonych Prowincji Niderlandzkich, będącej krajem zurbanizowanym, nowoczesnym, posiadającym wysoko rozwinięty handel oraz kulturę, jednak nieposiadającym kapitalistycznej gospodarki i nie działającym na zasadach kapitalistycznych ani w handlu, ani w produkcji. W drugiej części postaram się opisać krótko teoretyczne poglądy Meiksins Wood dotyczące teorii historii: znaczenia procesów i struktur w teorii historii oraz problemu politycznej roli historii. Omówię polemikę dotycząca procesualnego i strukturalistycznego podejścia w historii oraz analizę pojęcia „demokracji” jako władzy bezpośrednich producentów w antycznej Grecji jako kontrpropozycji dla konserwatywnych prób zawłaszczenia historii politycznej antyku dla uzasadnienia tendencji antydemokratycznych we współczesnej myśli politycznej (głównie amerykańskiego

\footnotetext{
${ }^{6}$ Poza pierwszą książka Mind and Politics: An Approach to the Meaning of Liberal and Socialist Individualism (Meiksins Wood 1972) nastepne prace, począwszy od opublikowanej po raz pierwszy w 1986 roku The Retreat from Class: A New „True” Socialism (Meiksins Wood 1998), wydane w kolejnych trzech dekadach stanowily rozwinięcie do formy ksiazżkowej wcześniejszych wątków, podejmowanych w artykułach. Do kategorii prac historycznych możemy zaliczyć: The Pristine Culture of Capitalism (Meiksins Wood 2015b), Peasant-Citizen and Slave: The Foundations of Athenian Democracy (Meiksins Wood 2015a), Citizens to Lords: A Social History of Western Political Thought from Antiquity to the Middle Ages (Meiksins Wood 2008), Liberty \& Property: A Social History of Western Political Thought from Renaissance to Enlightenment (Meiksins Wood 2012) oraz The Origin of Capitalism (Meiksins Wood 2002). Citizens to Lords oraz Liberty \& Property stanowia pewną całość, mająca postać podręcznika do „społecznej historii” myśli politycznej od antyku do nowożytności (od narodzin demokracji antycznej do początków kapitalizmu). Do prac teoretycznych należa natomiast: Mind and Politics: An Approach to the Meaning of Liberal and Socialist Individualism, The Retreat from Class: A New »True« Socialism (Meiksins Wood 1998) oraz Democracy Against Capitalism: Renewing Historical Materialism (Meiksins Wood 2016). Jest to podział nieco umowny, gdyż Meiksins Wood, będąc przede wszystkim historyczką, we wszystkich swoich książkach dba o historyczne uzasadnienie swych wywodów (dlatego można powiedzieć, że pierwsza grupa stanowi książki stricte historyczne, natomiast druga oparte na wiedzy historycznej książki teoretyczne). Najlepszym tego przykładem jest jedyna niewymieniona powyżej samodzielna praca autorki - Empire of Capital (Meiksins Wood 2003), która, choć podejmuje problem społecznoekonomicznych podstaw projektów imperialnych w historii, takich jak imperia rzymskie czy chińskie, hiszpańskie, arabskie, weneckie, holenderskie, brytyjskie czy w końcu amerykańskie, to nie szuka dla tych różnorodnych projektów wspólnego mianownika, ale właśnie istotnych różnic, dzięki którym możliwe jest określenie specyfiki poszczególnych formacji społecznych. Jednocześnie stawką polityczną książki jest wskazanie, w jaki sposób w erze zglobalizowanego kapitalizmu kapitał nie dąży do utworzenia globalnego państwa, a wręcz przeciwnie polega w coraz większym stopniu na podzielonych państwach terytorialnych, gdzie częściowej globalnej integracji towarzyszą równie silne tendencje do segmentacji i budowania podziałów (Meiksins Wood 2005, 15).
} 
i brytyjskiego populistycznego neokonserwatyzmu). Zauważyć bowiem należy, że dla Meiksins Wood demokracja jest procesem wspólistniejącym z kapitalizmem, lecz zasadniczo z nim niekompatybilnym. Jednak wpierw doprecyzuję pojęcie „marksizmu politycznego”.

Choć powstało jedynie jako niezamierzony produkt uboczny debat teoretycznych dotyczących Marksowskiego pojęcia „sposobu produkcji”, pojęcie „marksizmu politycznego” oddaje dość dobrze charakter podejścia autorki (Meiksins Wood 2016, 23-31). Podstawowym założeniem, które zostało, zdaniem Meiksins Wood, bez modyfikacji przejęte przez nią od Karola Marksa, jest przekonanie, że to stosunki społeczne, odpowiedzialne nie tylko za (re)produkcje samych ludzi, ale i jednocześnie (re)produkcję samych tych stosunków, sa podstawa dla zrozumienia, czym jest ludzkie społeczeństwo ${ }^{7}$. Stosunki te maja wiele partykularnych historycznie postaci, zaś tym, co je przede wszystkim określa, jest ich produkcyjny charakter, będący jednocześnie stosunkiem władzy, wyznaczającym polityczny charakter danego społeczeństwa ${ }^{8}$. Do tego podstawowego założenia odnosi się zwykle też krytyka marksizmu politycznego, w której podkreśla się jego „woluntaryzm”. Z perspektywy marksizmu politycznego sposób produkcji jest sposobem (re)produkcji określonych stosunków społecznych, np. w procesie akumulacji kapitalistycznej wraz z produkcją towarów produkowane są kapitalistyczne stosunki społeczne, będące stosunkami władzy i dominacji.

\footnotetext{
${ }^{7}$ Marks w drugiej części trzeciego tomu Kapitału, w rozdziale pięćdziesiątym pierwszym Stosunki podżału i stosunki produkciji, wyjaśnia najbardziej wprost (choć implicite jest ono obecne w całym Kapitale) pojęcie społecznych „stosunków produkcji” czy też społecznego „procesu produkcji”. Konfrontując swoją teorię z tym, w jaki sposób ekonomia polityczna przedstawia społeczny proces produkcji jako problem podziału dochodu społecznego między klasami, Marks kładzie nacisk na jego specyfikę (wyróżnia jako jego dwie podstawowe cechy to, że produkty są wytwarzane jako towary oraz to, że wytwarzanie wartości dodatkowej stanowi cel i „bodziec” czy przesłankę produkcji w kapitalizmie; Marks 1982, 652-654) oraz historyczność, a zatem i określoność dla danego okresu: ,jeżeli kapitalistyczny sposób produkcji ma za przesłankę ową określoną społeczną postać warunków produkcji, to nieustannie ją reprodukuje. Nie tylko wytwarza produkty materialne, lecz reprodukuje też nieustannie stosunki produkcji, w których wytwarza się owe produkty, a tym samym reprodukuje również odpowiednie stosunki podziału". (Marks 1982, 651-652). Fakt, że obok produkcji towarów sposób produkcji oznacza również (re)produkcję społecznych stosunków niezbędnych dla jego funkcjonowania sprawia, że: „[g]łówni agenci samego tego sposobu produkcji, kapitalista i robotnik najemny, sa jako tacy jedynie wcieleniem, uosobieniem kapitału i pracy najemnej; sa określonymi aktorami społecznymi, w których role społeczny proces produkcji wtłacza jednostki; są wytworami tych określonych społecznych stosunków produkcji”. (Marks 1982, 653). Określonym aktorom społecznym stosunki te są zwykle dostępne właśnie ze względu na ich funkcję w tym procesie i sposób, w jaki reprodukują własne życie społeczne (osiagają dochód i utrzymują swoja pozycję społeczna), dlatego też: „[t]ak zwane stosunki podziału odpowiadaja zatem i zawdzięczają swe powstanie historycznie określonym, specyficznie społecznym formom procesu produkcji oraz stosunkom, które nawiązuja ze sobą ludzie w procesie reprodukcji swego życia". (Marks 1982, 658). Stosunki produkcji nigdy zatem nie ograniczaja się do żadnej gospodarczej podstawy życia społecznego, a raczej określają, w jak samo życie przedstawicieli danych klas jako przedstawicieli tych klas jest (re)produkowane w kapitalistyczny sposób.

8 Robert Brenner w swojej późniejszej twórczości nazywa stosunki te „stosunkami reprodukcji” odpowiedzialnymi za klasowo określoną „strategię reprodukcji” jednostek i grup należących do danej klasy społecznej, odpowiadającej zarówno za ukonstytuowanie się wspólnoty politycznej, jak i bezpośrednia reprodukcję życia jej członków (Brenner 2007).

9 Alex Callinicos krytykował na łamach New Left Review marksizm polityczny za „,woluntaryzm” oraz niechęć do odwoływania się do wyjaśnień strukturalnych sprzeczności stosunków produkcji i sił wytwórczych, skutkiem czego określa to stanowisko jako zaledwie „socjologię dominacji” (Callinicos 1990, 110-115).
} 
Jest to sposób, w jaki kapitaliści określaja jednocześnie formę i wymiar pracy oraz konsumpcji klasy pracującej, a także polityczne warunki reprodukcji społeczeństwa kapitalistycznego. Ujmując problem krótko: „sposób produkcji” jest zawsze jednocześnie sposobem produkcji danego społeczeństwa jako społeczeństwa i klas jako klas (Marks, Engels 1984, 131). Sama Meiksins Wood podkreśla, że jej badania stanowia próbę odnowy i skutecznego, teoretycznego zastosowania poglądów Marksa z Kapitału (Meiksins Wood 2016, 21-36). Co więcej, założenie to nie ogranicza się do użycia metody Marksa. Jednym z najciekawszych aspektów badań Meiksins Wood jest to, iż uznaje ona metodę Marksa za nierozerwalnie związaną z przedmiotem jego badań w Kapitale, czyli z rozwojem kapitalizmu w Anglii ${ }^{10}$. Bez zrozumienia, w jaki sposób kapitalizm rozwinął się w tym kraju, w swojej partykularnej formie, w ogóle nie możemy prawidłowo pojąć, jaka jest jego specyfika. Nie oznacza to oczywiście, że Anglia zostać powinna uznana za powszechnie obowiązujący model rozwoju gospodarki kapitalistycznej - wręcz przeciwnie; więcej na ten temat dalej w niniejszym opracowaniu (por. Teschke 2011). Celem Marksa w Kapitale było stworzenie modelu „kapitału w ogóle” (Marks, Engels 1968, 6-7, Marks, Engels 1984, 578 Heinrich 2012, 30-32), jednak nawet jeżeli stosunki kapitalistyczne nabrały abstrakcyjnej postaci, możliwej do ujęcia w abstrakcyjnej teorii, to maja swoje bardzo konkretne i materialne pochodzenie, czego wyrazem w samym Kapitale jest bardzo obszerny i wcześnie napisany tzw. czwarty tom, czyli Teorie wartości dodatkowej oraz oczywiście fakt, że model teoretyczny jest, mimo swojego abstrakcyjnego charakteru, modelem funkcjonowania kapitalizmu angielskiego. Teorie kapitalizmu mylące porządki genezy logicznej i historycznej prowadzą do metafizycznych i teleologicznych konstrukcji, opartych na schemacie błędnego koła (Meiksins Wood 2016, 136, 151).

\section{Pochodzenie kapitalizmu}

W przedmowach do swoich książek Meiksins Wood często podkreśla własne zadłużenie względem Roberta Brennera. W głośnym artykule „Agrarian Class Structure and Economic Develompent in Pre-Industrial Europe" przeciwstawia on dwu modelom wyjaśnień powstania kapitalizmu - „modelowi demograficznemu” (neomaltuzjańskiemu) oraz „modelowi handlowemu" (neoricardiańskiemu; Brenner 1976, 32) - swoje własne wyjaśnienie, zgodnie z którym początki kapitalizmu wiązać należy nie ze wzrostem demograficznym czy rozwojem

10 Zarówno Brenner, jak i Meiksins Wood skupiają się na okresie od piętnastego do siedemnastego wieku, czyli epoce tzw. „agrarnego kapitalizmu”. Choć jest to okres poprzedzający industrializację i głębokie przekształcenia społeczne z nią związane, stanowi czas równie burzliwych przemian, zwykle postrzeganych jako okres „rozmontowywania” feudalnych stosunków społecznych. Amerykańscy historycy wskazują jednak, że jest to również czas powstania kapitalistycznych stosunków produkcji, które nie tyle zastapiły stosunki feudalne, ale wyrastaja z trwającego kilkaset lat kryzysu i dramatycznych przekształceń społeczeństwa angielskiego (Meiksins Wood 2002 131-143, Brenner 2007, Dimmock 2015, 11-33). 
handlu, lecz z określonymi stosunkami produkcji i własności ${ }^{11}$. Wyjaśnienie powstania kapitalizmu nie może opierać się, zdaniem Brennera, na czynnikach określających, w ten lub inny sposób, rozwój mechanizmów rynkowych. Jego zdaniem należy wskazać, jak tego typu mechanizmy w ogóle zaczęły grać decydującą rolę oraz w jaki sposób powstało społeczeństwo, w którym rynek staje się źródłem prąymusu i czynnikiem regulującym życie społeczne. Konieczne jest więc rozwikłanie procesu powstania samych tych mechanizmów jako stosunków społecznych. Nie należy zaczynać od poszukiwań kategorialno-ontologicznego nośnika stosunków społecznych, takiego jak „technika”, a od samego systemu relacji w przeciwnym razie analiza ulega ideologicznej depolityzacji.

Wspomniane dwa modele maja zwykle tendencję do neutralizowania klasowego charakteru mechanizmów rynkowych, wobec czego należy wyjść od klasowej struktury społeczeństwa i określić dynamikę rozwoju stosunków klasowych w dwóch podstawowych aspektach: rozwoju sił wytwórczych oraz stosunków własności (Brenner 1976, 31) ${ }^{12}$. Innymi słowy, trzeba zbadać społeczny charakter produkcji (nie redukując zjawiska produkcji do rozwoju technologii, populacji czy form politycznej kontroli). Nie miejsce tu na dokładniejsza rekonstrukcję argumentu Brennera, warto jednak wskazać na istotny płynący z niej wniosek. Kapitalizm, konstytuujące go stosunki społeczne, nie tworzą żadnej uniwersalnej logiki i nie są preegzystująca w zalażzowej postaci formą ludzkich relacji. Kapitalistyczne stosunki produkcji powstały w wyniku ewolucji niekapitalistycznych stosunków agrarnej produkcji w Anglii, gdzie kluczową rolę wśród czynników endogenicznych (tych dotyczących struktury klasowej samego społeczeństwa) pełniły określona forma stosunków własności (wysoka koncentracja) oraz określone warunki polityczne (formy prawa i państwa). Zespół czynników egzogenicznych takich jak np. czarna śmierć czy później napływ złota z kolonii jest określany jako „kryzys późnego średniowiecza”. Gdy pytamy o genezę kapitalistycznego sposobu produkcji, musimy stwierdzić, że to ten jeden konkretny sposób produkcji, powstały w Anglii (co nie znaczy, że Anglia była monada i że można zrozumieć te przemiany bez rozumienia historii regionu). Zarówno sam kapitalizm, jak i jego abstrakcyjny, ponadnarodowy charakter, maja swoja konkretna, materialną i ściśle historyczną genezę (opisywany już w Kapitale proces powstawania globalnego podziału pracy i rynku światowego) (Marks 1968, 537; Marks 1984, 404, 685). Kapitalizm nie zaczął się, zgodnie z weberowskimi mitologiami, od heroicznych wysiłków brytyjskich czy holenderskich kupców, którzy dzięki swojej oszczędności i pomysłowości usprawnili produkcję. Nie powstawał jako siła uwalniająca moce społeczeństwa od ograniczeń

11 Ciekawa dyskusja na temat modelu handlowego, „tezy Brennera” oraz znaczenia samego politycznego marksizmu odbyła się na łamach International Socialist Review (Brich i Heideman 2013, Davidson 2013, Post 2014, Anievas i Nisancioglu 2014), a także International Socialism (Brenner, Harman 2006).

12 Wyjaśnienie powstania kapitalizmu w Anglii w syntetycznej i uproszczonej postaci można znaleźć w obszernym artykule Brennera „Property and progress: Where Adam Smith Went Wrong” (Brenner 2007). 
porządku feudalnego. Od poczatku opierał się na dominacji klasowej wielkich posiadaczy, mających oparcie w potężnym aparacie państwowym, i na wytworzeniu przymusu zależności rynkowej, dotyczącej w fazie agrarnego kapitalizmu pracowników rolnych i dzierżawców oraz samych posiadaczy ziemskich (którzy uczynili z ziemi towar, którego wartość zależała od praw rynku, a nie od tradycji i prawa zwyczajowego). Pierwsi kapitaliści wcale nie byli tak wrogo nastawieni do feudalizmu, a narodziny kapitalizmu nie wiązały się z „wybuchem wolności”, lecz raczej z przemiana jednych form zależności i przymusu w inne. Podkreślany zwykle „wolnościowy” charakter rozwoju kapitalizmu trzeba rozpatrywać w kategoriach określonych migracji między klasami oraz wytwarzania się nowych klas społecznych. Należy też zawsze pamiętać, że ta sama wolność może mieć różne znaczenie dla reprezentantów różnych klas. Formalnie identyczne pojęcie wolności może realnie mieć diametralnie inne konsekwencje (oznaczać dla jednych nędzę gorszą od tej doświadczonej w średniowieczu, a dla innych bogactwo przekraczające wyobrażenia wszystkich średniowiecznych władców).

Sformułowanie problemu powstania kapitalizmu w Anglii stanowi historyczną podstawę dla całego marksizmu politycznego - o tyle, że ustanawia w badaniach historycznych podstawę dla prymatu stosunków klasowych w wyjaśnieniach procesów historycznych ${ }^{13}$. O materialnym kształcie tych stosunków możemy dowiedzieć się jedynie z przekazów historycznych. Nie da się tego zrobić czysto teoretycznie, ani też rekonstruując jedynie kulturowy czy dyskursywny charakter tychże przekazów. Nie oznacza to bynajmniej, że czynniki takie jak rozwój technologiczny, wahania populacji, czy stosunki wymiany i wiele innych, nie grają ważnej roli. Stosunki klasowe maja syntetyczny charakter, to znaczy, że maja materialną, historyczna, złożona postać, czy też formę społeczną, łączącą te różnorodne aspekty życia społecznego. Wykładnia takich stosunków jako abstrakcji określonej nie jest nigdy pracą teoretyczna, pozbawioną empirycznego i politycznego znaczenia. Dlatego też należy analizować te czynniki tak, jak analizował je Marks, podkreślając polityczne znaczenie technologii, rozwój produkcji maszynowej w rozdziale „Maszyna i wielki przemys»” w pierwszym tomie Kapitału, gdzie stwierdza, że „Maszyna jest środkiem do wytwarzania wartości dodatkowej” (to jest jej podstawowy cel określony przez stosunki produkcji w kapitalizmie) (Marks 1968, 438), ale i narzędziem uspołecznienia robotnika (wpływającym na poziom populacji, wykształcenie

\footnotetext{
${ }^{13}$ Ciekawą, przeprowadzoną z bardzo wysokiego poziomu abstrakcji teoretycznej, analize podejścia Brennera w odniesieniu do jego teorii kryzysu przedstawia w swoim artykule amerykański marksista Toni Smith. Autor stara się bronić podejścia Brennera przed zarzutami Michaela Lebowitza, zgodnie z którymi Brenner przyznaje prymat w wyjaśnieniu kryzysów, podobnie jak jego zdaniem Baran i Sweezy, relacjom pomiędzy poszczególnymi kapitalistami (Baran, Sweezy 1968), a nie ruchowi kapitału w ogóle, przez co zdaniem Lebowitza odchodzi zupełnie od metody Marksa. Choć problematyka artykułu Smitha nie jest bezpośrednio związana z poruszanymi przeze mnie kwestiami, to stanowi głęboki teoretyczny wgląd w podstawy teoretyczne Brennera - właśnie dlatego, że Lebowitza niepokoi właśnie to samo podejście, które Brenner dostrzegał określał jako „neoricardianizm” i które zwalczał w teorii, a zatem jest próbą zwrócenia przeciwko samemu Brennerowi jego własnej argumentacji (Smith 1999).
} 
i kulturę robotników, czas pracy, rozwój stosunków klasowych i wyzysku). Maszyna, produkując towary, (re)produkuje jednocześnie określoną formę produkcji oraz formę społeczeństwa, a zatem jest, w równym stopniu co produktem wiedzy naukowej, produktem określonych stosunków klasowych (Marks, Engels 1984, 129-131, 157-158).

W swojej pracy The Origin of Capitalism Meiksins Wood przeprowadza drobiazgowa analizę przebiegu debaty na temat powstania kapitalizmu. Analizę tę rozpoczyna od polemiki Marksa z przedstawicielami klasycznej ekonomii politycznej oraz jego krytyki pojęcia „akumulacji pierwotnej”, a kulminuje w odniesieniu do debaty Maurice’a Dobba z Paulem Sweezym i kontynuowanej później przez historyków takich jak Perry Anderson czy właśnie Robert Brenner (ten etap debaty nazywany jest „debatą brennerowską"14) (Ashton i in. 1985) ${ }^{15}$. Zdaniem Meiksins Wood, zasługa Brennera polega na trafnym rozwinięciu debaty, łączącym najlepsze części argumentów wymienionych teoretyków. Maurice Dobb, podobnie jak Rodney Hilton, za najważniejszy czynnik rozwoju kapitalizmu uważał konflikty klasowe w obrębie późnego społeczeństwa feudalnego (występując przeciwko liberalnym i konserwatywnym wyjaśnieniom, wiążącym kapitalizm z handlem i rozwojem miast, takimi jak teoria Maxa Webera) (Meiksins Wood 2016, 146-181, Meiksins Wood 2012, 3-9, 81-84, Meiksins Wood 2002, 191-192). Sweezy natomiast był zdania, że decydujące znaczenie posiadał rozwój handlu na ponadnarodowa skalę, wymykającego się kontroli państwa feudalnego, oraz późnośredniowieczny kryzys możliwości kontroli pracy za pomoca feudalnych mechanizmów. Dobb i Hilton atakowali Sweezy’ego, ponieważ uważali jego wyjaśnienie za nadające prymat stosunkom wymiany, a nie stosunkom produkcji. Natomiast Sweezy wskazywał na fakt, że wyjaśnienie Dobba i Hiltona, choć stawia w centrum konflikt klasowy, dotyczący stosunków produkcji w dobie późnego feudalizmu, nie ukazuje jednak, w jaki sposób konflikt ten doprowadził do pojawienia się kapitalistycznych stosunków produkcji. W konsekwencji wbrew pozorom ich teoria niewiele różni się od typowych narracji modelu handlowego. Zamiast twierdzić, że „zalążki kapitalizmu” preegzystowały w handlowych metropoliach, Dobb i Hilton twierdza, iż istniały one w gotowej postaci już na etapie produkcji agrarnej, która uległa

14 Początek debaty jest umowny, gdyż przed Smithem czy Marksem problemy te były oczywiście na swój sposób dyskutowane - zarówno w odniesieniu do kapitalizmu, jak i społeczeństw niekapitalistycznych. Sam Marks pisze Kapitał z perspektywy członka społeczeństwa niemieckiego (choć na emigracji w Wielkiej Brytanii), które jest jeszcze wówczas gospodarczo zacofane i łączy w sobie problemy różnych form gospodarczych i społecznych, chciałoby się powiedzieć: istnieje na przecięciu różnych sposobów produkcji (Meiksins Wood 2002, 11-33). Niezwykle ciekawą analizę teoretycznych ujęć tworzenia kapitalizmu w jego wczesnej postaci przedstawil w swojej książce The Invention of Capitalism: Classical Political Economy and the Secret History of Primitive Accumulation amerykański ekonomista i historyk Michael Perelman (Perelman 2004).

15 Szczegółowa analizę debaty przejścia od kapitalizmu do feudalizmu można znaleźć także w książce Spencera Dimmocka The Origin of Capitalism in England: 1400-1600 - w szczególności debaty dotyczące podejścia Meiksins Wood i Brennera w rozdziale drugim ,The Prime Mover of Economic and Social Development”, w którym autor omawia krytykę ze strony historyków i ekonomistów nie-marksistowskich, oraz w rozdziale ósmym, „Orthodox Marxism versus Political Marxism”, w którym omawia krytykę ze strony samych marksistów (Dimmock 2015). 
ekspansji. Teoria Brennera stanowi w zasadzie modyfikację wyjaśnienia Dobba, zabezpieczoną jednak przed bardzo poważnym zarzutem Sweezy’ego. Różnica między Dobbem a Brennerem, pomimo wszystkich podobieństw, sprowadza się do problemu aktora zmian: dla Dobba byli to mali i średni producenci, natomiast dla Brennera kompozycja ta jest bardziej złożona i uwzględnia również „dużych” aktorów (Meiksins Wood 1996). By przemyśleć ten problem, Brenner i Meiksins Wood musieli jednak dokonać rekonstrukcji całej struktury pojęciowej marksizmu. Późnośredniowieczne stosunki społeczne w Anglii, gdzie przechwytywanie nadwyżek oparte było przede wszystkim na rencie gruntowej, nie zostały zastapione przez „uwolnioną" logikę kapitalistyczna. To same feudalne stosunki społeczne nabrały kapitalistycznego charakteru. Uwłaszczenie chłopstwa było jednocześnie urynkowieniem produkcji rolnej, a więc urynkowieniem środków produkcji chłopów, prowadzącym do ich koncentracji w rękach kapitalistów i jednocześnie proletaryzacji tych pierwszych. Nie było żadnej pierwotnej akumulacji w sensie długiego procesu nagromadzenia kapitału (w niemarksowskim rozumieniu) w niekapitalistycznych warunkach ${ }^{16}$. Kapitalistyczne stosunki społeczne pojawiły się w sytuacji, w której własność była już silnie skoncentrowana, krajowy rynek połączony, a aparat państwowy scentralizowany i umocniony. Dynamika rozwoju

16 Jak wskazują włoscy teoretycy postoperaistyczni (Mezzadra 2014, De Angelis 2001, Bonefeld 2001), „akumulację pierwotna” należy rozpatrywać jako ciagły proces separacji bezpośrednich producentów od środków produkcji (podobnie widzi to Meiksins Wood, Meiksins Wood 2016, 21). Różnica między formalnym a realnym podporządkowaniem pracy kapitałowi nie polega na skoku od „wydarzenia” pierwotnej akumulacji o charakterze ilościowym (pierwotne nagromadzenie kapitału stałego) do jakościowo nowego procesu produkcji kapitalistycznej (sposobu produkcji). Realne podporządkowanie pracy kapitałowi oznacza podporządkowanie istniejących form organizacji pracy samemu procesowi akumulacji i w konsekwencji przekształcenie ich. Nie oznacza to jedynie, jak można by sądzić, że w procesie realnego podporządkowania subsumpcji ulegają tylko kapitalistyczne formy organizacji pracy (np. kapitał przemysłowy zostaje podporządkowany finansowemu). W rzeczy samej, jednym z najciekawszych wątków tradycji operaismo jest dostrzeżenie, że kapitalizm rodzi niekapitalistyczne formy organizacji pracy czy formy życia, nazywane przez część postoperaistów dobrem wspólnym (lub pracą biopolityczna). Dobro wspólne, właśnie dlatego, że jest dokładnym przeciwieństwem separacji producentów od środków produkcji, jest nie do pogodzenia na poziomie formalnym z kapitalistycznym sposobem produkcji. Niemniej jednak możliwe staje się jego podporządkowanie niebezpośrednie (realne), w którym nie ingerując w proces pracy i życia, kapitał jest zdolny do ekstrakcji wartości z dóbr wspólnych. Nierozdzielność producenta i środków produkcji w dobru wspólnym wynika z samego faktu, że to twórcza podmiotowość wielości, „żywa praca” czy też „praca biopolityczna”, stanowi samo owo dobro. Problem, jaki dla mnie wyłania się z tych debat, to problem organizacji przeciwstawnej do realnego podporządkowania kapitałowi. O ile produkcja dobra wspólnego sama w sobie (nawet na mocy samej swojej definicji) jest sprzeczna z kapitalistycznym sposobem produkcji, to sama ta sprzeczność oczywiście może być funkcjonalna względem tejże produkcji w pośredni sposób (np. przez zawłaszczenie samych mynikón procesu produkcji), a więc realnie podporządkowana kapitałowi (choć formalnie sprzeczna); np. cały trick gentryfikacji polega na jednoczesnym zachowaniu autonomicznej kultury lokalnej i sprzedaniu jej głodnym „inspirujących” miejsc burżua. Analogicznie do podziału na formalne i realne podporządkowanie nie należy interpretować tych relacji zbyt prosto. To, że produkcja podmiotowości, praca biopolityczna, czy produkcja dobra wspólnego stanowi o możliwości oporu wobec kapitału, nie znaczy, że będzie stanowić o możliwości walki z nim. Tak samo jak proces proletaryzacji według Marksa, proces wyzysku pracy biopolitycznej według postoperaistów, jako procesy wytwarzania podmiotowości, stanowią o możliwości akumulacji kapitalistycznej, a jej granice wyznacza dynamika tych procesów (walka klas). Mikroekonomia dóbr wspólnych może być, i była w przeszłości, zawsze uzgadniana z makroekonomicznymi strukturami nie mającymi z nim nic wspólnego, podobnie jak antykapitalistyczne czy emancypacyjne ruchy społeczne były podporządkowywane reakcyjnym partiom politycznym. 
stosunków klasowych w Anglii prowadzi do zastapienia „politycznie ukonstytuowanej własności” (pojęcie Brennera, używane bardzo często w pracach Meiksins Wood) poprzez mechanizmy rynkowe (zarówno dotyczące samej produkcji, jak i własności). Skutkiem dla kapitalistów jest konieczność podlegania presji mechanizmów konkurencji (powodującej konieczność powiększania i usprawniania produkcji, czyli przechwytywania wartości dodatkowej), a dla bezpośrednich wytwórców - zależnością od rynku, nawet w kwestii najbardziej podstawowych potrzeb życiowych (uleganie procesowi proletaryzacji, „wolności” od pozarynkowego dostępu do środków konsumpcji oraz „prawa” do sprzedaży własnej siły roboczej) ${ }^{17}$. Meiksins Wood bardzo często podkreśla, że owe mechanizmy stają się dominujące, gdy rynek staje się dla przedstawicieli wszystkich klas imperatywem, a nie jedynie możliwościa (Meiksins Wood 2016, 118-121). Wymiana rynkowa jako taka istniała oczywiście przed kapitalizmem, tak jak różne formy kapitału istniały przed kapitalizmem, a wyjaśnienia domaga się nie domniemana sprawczość rynków czy kapitału, ale ich funkcja w procesie przemiany społeczeństwa angielskiego ${ }^{18}$.

Warto tutaj zrozumieć kolejność wynikania w wyjaśnieniu. Postęp techniczny jest formą przemiany kapitalistycznych stosunków społecznych, nie odwrotnie. Przemianę tę można ująć, określając rewolucje przemysłową jako rozwój technicznych środków pozyskiwania wartości dodatkowej, wynikający z przymusu rynkowego reinwestycji nadwyżek w sam proces produkcji. Usprawnienie produkcji jest wynikiem kapitalistycznych stosunków społecznych, gdzie to rynek jest źródłem przymusu: właściciele chcą i muszą wykorzystać presję rynku na swoja korzyść. Zupełnie inaczej wygląda to w społeczeństwie niekapitalistycznym, gdzie przymus

\footnotetext{
17 Zgodnie z taką interpretacja, w świetle której zmiana stosunków klasowych poprzedza chronologicznie i logicznie zmiany technologiczne „rewolucji przemysłowej” czy rozwój demograficzny, Meiksins Wood rozumie procesy kształtowania się klas w Anglii opisane w The Making of the English Working Class E.P. Thompsona (Wood 2002, 50-71). Czytelnik może, zapoznając się z pracą brytyjskiego historyka, ze zdumieniem odkryć, że ogromna jej część poświęcona jest opisowi politycznej organizacji klasy pracującej, jej formowania się - nie zgodnie z mechanizmami rozwoju kapitalistycznych stosunków społecznych jako prostego ideologicznego odbicia nowej formy gospodarki, ale jako wyrazu sprzeciwu i walki klasowej, zasilanej głównie wyobrażeniami, argumentami, formami organizacji politycznej i społecznej, zaczerpniętymi z tradycji społeczeństw niekapitalistycznych, takich jak na przykład formy organizacji rzemieślniczej czy wspólnoty religijne (Thompson 1964). Ksiażka Thompsona skupia się właśnie na tym problematycznym okresie - latach od 1780 do 1832, kiedy to trudno uznać rewolucję przemysłowa za dokonana, jednak zachodzi wiele kluczowych dla powstania klasy pracującej i zarazem kapitalizmu procesów społecznych. Praca Thompsona poucza, że alternatywą dla kapitalizmu może być nie tylko modernistycznie wyobrażona przyszłość, ale i, w równym stopniu, przeszłość, gdyż jest ona w kapitalizmie, przez proces utowarowienia, co najmniej równie obecna w świadomości robotników, jak przyszłość.

18 Zapoczątkowana przez samego Marksa w Kapitale fiksacja na badaniu samego kapitału, jego składu, tendencji czy historycznych form sprawia, że wielu marksistów uznaje, iż historia kapitalizmu jest historia kapitału. Badania amerykańskich marksistów pouczaja jednak, że początek kapitalizmu wiąże się z narodzinami społeczeństwa kapitalistycznego (kapitał istniał i przed nim), a więc społeczeństwa, którego reprodukcja jest oparta na procesie akumulacji kapitału i podporządkowana (subsumpcja) kapitałowi. Rozwój kapitału w ogóle jest tylko o tyle interesujący, o ile stał się on wehikułem przemian społecznych dokładnie w takim sensie, w jakim Marks w pierwszym zdaniu Kapitału podkreśla, że produkcja kapitalistyczna jest interesująca o tyle, o ile jest obecnie panująca historyczną formą bogactwa spotecznego (Marks 1968, 39; por. Holloway 2017).
} 
iwładza maja swoje podstawy w czynnikach pozaekonomicznych, przede wszystkim w przewadze militarnej. Tutaj żadne usprawnianie produkcji nie jest konieczne (choć może się pojawić), ponieważ przewagę zyskuje się przez rozszerzenie potęgi militarnej oraz ekstensywne zwiększanie produkcji dzięki zwiększaniu liczby poddanych (podporządkowanych siłą, a nie presja rynkowa). Rynek stanowi podstawę kapitalizmu nie tylko dlatego, że stanowi o mechanizmach wymiany i dystrybucji dóbr, ale i dlatego, że jego mechanizmy staja się mechanizmami reprodukcji społeczeństwa (Meiksins Wood 2002, 97). Podstawowym efektem urynkowienia produkcji agrarnej w początkowej fazie rozwoju kapitalizmu jest sprawienie, że cena dzierżawy gruntu zaczyna podlegać regulacji rynkowej (Meiksins Wood 2002, 130-132). Jest to zatem urynkowienie stosunków społecznych odpowiedzialnych za samą reprodukcję niezbędnych dla przeżycia środków konsumpcji agrarnego społeczeństwa Anglii. Dopiero w drugiej kolejności chodzi tu o wzrost populacji i urbanizacji oraz o tzw. rewolucję przemysłowa, która odbywa się już na gruncie stosunków kapitalistycznych i jest niemożliwa do zrozumienia w czysto technicznych kategoriach, gdyż stanowi także „rewolucję” polityczną i społeczna. Należy jednak pamiętać, że dotyczy ona wszystkich członków społeczeństwa, choć dotyka różnych klas w zupełnie różny sposób.

Świetnym przykładem obrazującym ten proces jest rozwój w Anglii tzw. literatury improvement (postępu, udoskonalenia), dotyczącej w dużej mierze usprawnień w produkcji rolnej i zarządzaniu dużą własnościa. Podstawowym przedmiotem jej zainteresowania są „nowoczesne metody” produkowania, a zatem przekształcenie samych stosunków produkcji. W literaturze tej, podobnie jak w teorii własności Locke’a, zawierającej już kapitalistyczną teorię wartości (Meiksins Wood 2012, 237, 262-287), postęp i rozwój nie są związane z technicznymi kryteriami wzrostu produkcyjności, rządzenia populacją, ani nie są motywowane moralnymi czy społecznym zapotrzebowaniem na żywność, a jedynie koniecznością wytwarzania zysku lub renty. Oznacza to, że wyłącznie powstająca klasa kapitalistów może zapewnić postęp i tylko ona de facto produkuje; robotnicy czy drobni dzierżawcy rolni sami z siebie są zacofani i leniwi (przywiązani do produkcji opartej na dobru wspólnym) ${ }^{19}$. „Bezproduktywność” jest zarówno określeniem niekapitalistycznych form własności, jak i podmiotowości - zatem „postęp”, o którym tu mowa, jest historycznym rozwojem imperatywu maksymalizacji zysków od pierwszych prób jego dyskursywnego ujęcia do świadomej teoretycznej eksplikacji w klasycznej ekonomii politycznej.

Świadomie takie rozumienie produktywności proponował już William Petty wysłany przez Olivera Cromwella do Irlandii w celu sporządzenia mapy wyspy, a zarazem wyceny

\footnotetext{
19 Por. analizy Petera Linebaugha, wskazującego w swoich dwóch książkach: Stop, Thief! The Commons, enclosures and resistance oraz The Magna Carta Manifesto, w jaki sposób można skutecznie stworzyć polityczną lekturę niekapitalistycznych form produkcji kontynuująca prace nurtu historii oddolnej (bistory from below), przedstawiającej historię narodzin kapitalizmu zarówno z perspektywy kapitału, jak i chłopów, robotników, czy wielości (Linebaugh 2008, Linebaugh 2014).
} 
wartości ziemi. Petty, uważany przez niektórych za ojca założyciela ekonomii politycznej, powiązał wartość ziemi z ilościa pracy koniecznej do jej uprawy (jako ziemi wydającej plony), nazywając tę ilość „ceną naturalną”. W The Political Anatomy of Ireland Petty nie ograniczył się do obliczeń wartości ziemi, przewidywał także możliwość „ulepszenia” samej ludności. Wycenił przeciętnego Irlandczyka za pomocą ceny niewolnika afrykańskiego, równej dwudziestu pięciu funtom i stwierdził, że możliwe jest doprowadzenie do potrojenia jego wartości i zrównania z przeciętną wartością Anglika, równą siedemdziesięciu funtom za osobę - pokazując w ten dosadny sposób, że nowa forma pracy produkującej na rynek i możliwej do kupienia na rynku jest podstawą kapitalistycznej ekonomii oraz nowej teorii wartości (Meiksins Wood 2005, 8485, por. Perelman 2004, 124-138).

Przedstawiona tutaj w zarysie debata o początkach kapitalizmu stanowi zaplecze teoretyczne dla rozważań Meiksins Wood. Z powodzeniem wykorzystuje ona Brennerowskie analizy - zarówno do swych własnych badań historycznych (o czym będzie mowa dalej) jak i do diagnoz obecnej sytuacji politycznej, a także w polemikach teoretycznych. Podsumowując, można powiedzieć, że cały ciężar argumentacji historyczno-teoretycznej marksizmu politycznego leży w podkreśleniu, że historyczny proces przejścia od formalnej do realnej subsumcji pod kapitał w Anglii jest przede wszystkim przejściem od pojawienia się i wytwarzania omówionych powyżej stosunków społecznych w obrębie produkcji agrarnej do świadomej i celowej produkcji tych stosunków za ich pomoca - wytwarzanie kapitalistycznych stosunków społecznych zgodnie z ich własną logika.

To powiązanie procesu produkcji kapitalistycznej i akumulacji kapitału z procesem reprodukcji społeczeństwa stanowi o wyjątkowym charakterze kapitalizmu. Tylko w kapitalizmie dokonuje się przekształcenie społeczeństwa, które zgodnie z terminologia Marksa można nazwać „względna praca dodatkową” (w analogii do „względnej wartości dodatkowej”) z która pojawia się przymus usprawniania technicznego procesu produkcji, a wraz z nim samonapędzający się wzrost gospodarczy (Brenner 1995, 30, 68). Oparty na tej formie pracy „system pozyskiwania nadwyżek” jest czymś zupełnie wyjątkowym, a skupienie uwagi na tej specyficznej dla kapitalizmu formie pracy pozwala dostrzec problem, który Brenner w artykule The Origins of Capitalist Development przedstawił jako zarzut względem perspektywy, którą nazywa „neosmithiańską”, reprezentowanej według niego przez m.in. André Gundera Franka oraz Immanuela Wallersteina. Dla Wallersteina, zdaniem Brennera: „[R]ozwój ekonomiczny jest ilościowy, odznacza się: 1. rozwojem rozmiaru systemu przez ekspansję, 2. reorganizacją środków produkcji przez regionalną specjalizację mająca na celu zwiększenie efektywności, 3. transferem nadwyżek.” (Brenner 1995, 31)20. Wszystkie te cechy

\footnotetext{
${ }^{20}$ Ciekawą, choć nie w pełni przekonująca krytykę podejścia Brennera do wyjaśniania powstania kapitalizmu w odniesieniu do debaty Brenner-Wallerstein i kluczowego zdaniem autorów dla oceny tego podejścia przykładu, czyli rozwoju gospodarczego Polski w XV i XVI wieku, przedstawiaja w swoim artykule The Brenner-Wallerstein
} 
spełnia kapitalistyczny system, jednak nie wystarczają one do jego charakterystyki. Błędność analiz wychodzących z założenia, że kapitalizm narodził się wraz z rewolucją w handlu czy rewolucją technologiczną polega często na tym, że wskazują one zjawiska, które istnieja zarówno w kapitalizmie, jak i w systemach niekapitalistycznych. Nie potrafiąc wskazać procesów odpowiedzialnych za (re)produkcję stosunków społecznych, nie prowadzą do zrozumienia możliwości (re)produkcji warunków radykalnej przemiany społecznej. Sprawa ta ma tak duże znaczenie, gdyż tylko specyficzna forma pracy, jako rozwoju względnej pracy dodatkowej, może być podstawą (re)produkcji takiej przemiany. Z taką zmianą, łącząca moc polityczną i produkcyjna pracy, wiąże Meiksins Wood pojęcia demokracji i socjalizmu (Meiksins Wood 2016, 21, 48, 290). Oczywiście krytyka teorii zbiorczo określonej jako „neoricardiańskie modele”, „modele handlowe”, czy „burżuazyjny paradygmat”, nie służy odrzuceniu w całości teorii zależności czy teorii systemów światów, lecz skutecznej krytyce ich najsłabszego punktu, czyli tendencji do pomijania roli stosunków produkcji i wytwarzania wartości dodatkowej na rzecz stosunków wymiany.

Przedstawię teraz badania historyczne Meiksins Wood, wskazujące na przykłady historycznego rozwoju handlu opartego na niekapitalistycznych zasadach, jak i produkcji kapitalistycznej, opartej nie na wolnym handlu, a na przymusie dotyczącym produkcji rolnej. W problematyce tej skupia się bardzo wiele kwestii teoretycznych - tutaj przedstawię wybrane badania historyczne, dotyczace niekapitalistycznego imperium handlowego Republiki Zjednoczonych Prowincji Niderlandzkich.

\footnotetext{
Debate dwaj amerykańscy teoretycy Robert A. Denemark i Kenneth P. Thomas. Ich zdaniem przykład Polski wskazuje błędność podejścia Brennera, które ich zdaniem jest wystarczające jedynie do analizy procesów na poziomie gospodarek poszczególnych państw i w związku z tym niezdolne do analizy szerszych procesów, takich jak wprowadzenie wtórnego poddaństwa w Polsce oraz zależności handlowe w skali Europy. Niezależnie od oceny krytyki przedstawionej w artykule, należy zaznaczyć, że trafia ona w jeden z najważniejszych problemów teorii marksizmu politycznego, czyli kwestię zależności pomiędzy gospodarkami kapitalistycznymi i niekapitalistycznymi oraz rozumienia związku między relacjami charakterystycznymi dla kapitalistycznego sposobu produkcji i takimi, które z nimi współistnieja, nie mając prostego związku z samym kapitalizmem. Brenner oczywiście odrzuca analizę systemów-światów jako podejście de facto neoricardiańskie, jednak, jak słusznie zauważają autorzy, główny przedmiot zainteresowania Wallersteina to właśnie ten problem, który jest w marksizmie politycznym najbardziej zaniedbany. W efekcie uznaja, że podejścia te do pewnego stopnia uzupełniają się, przyznając jednak wyższość analizie systemów-światów w kluczowej, ich zdaniem, analizie polskiej gospodarki (Denemark i Thomas 1988).
} 


\section{Produkcja i handel: specyfika kapitalizmu}

Meiksins Wood wiąże, podobnie jak Brenner, powstanie kapitalizmu z określonymi stosunkami społecznymi, powstałymi w Anglii, a zatem przemiana jednej z wielu form niekapitalistycznych stosunków klasowych w stosunki kapitalistyczne. Takie ujęcie pochodzenia kapitalizmu ma bardzo istotne konsekwencje zarówno dla rozumienia dalszego rozwoju kapitalizmu, jak i dla rozumienia społeczeństw niekapitalistycznych. Materializm historyczny staje się teoretycznym narzędziem zwalczania takich sposobów rozumienia historii, w ramach których przeszłość stanowi różne formy „prefiguracji” teraźniejszości, a także ukrytych form teleologii w historii. Pojęcie społeczeństw niekapitalistycznych nie oznacza tutaj społeczeństw „prekapitalistyczych”, kapitalistycznych in spe. W pracach historycznych Liberty and Property oraz Citizens to Lords Meiksins Wood konstruuje społeczną historię myśli politycznej od antyku do wczesnej nowożytności (historię filozofii polityki społeczeństw niekapitalistycznych). Zasadnicze założenie jest podobne, jak w być może bliższej polskiemu czytelnikowi książce Étienne’a Balibara Spinoza i polityka (Balibar 2009), gdzie autor w celu rekonstrukcji myśli politycznej Spinozy drobiazgowo rekonstruuje kontekst społeczno-polityczny, umieszczając poglądy filozofa w kontekście walk politycznych w siedemnastowiecznych Niderlandach. Podobnie Meiksins Wood wychodzi z założenia, że to struktura stosunków społecznych, w których tworzyli i działali teoretycy, jest warunkiem wstępnym ich zrozumienia (w ten sposób bada poglądy Spinozy czy Grocjusza).

Republika Zjednoczonych Prowincji Niderlandzkich - istniejąca w okresie pomiędzy szesnastym i osiemnastym wiekiem, zgodnie z modelem handlowym powinna być idealnym przykładem społeczeństwa protokapitalistycznego (Meiksins Wood 2012, 109-146). Główną przyczyna jej potęgi był zgodnie z takimi wyjaśnieniami handel. Ramy te wyznaczają okres od szesnastowiecznej rewolucji politycznej do siedemnastowiecznego „złotego wieku” i następującej po nim stagnacji i zatrzymania rozwoju w szerzej rozumianej historii Niderlandów. Wraz ze wzrostem siły niderlandzkiej żeglugi handlowej rozwijała się nie tylko kultura miejska, ale i technologia żeglugi oraz produkcji rolnej (produkowano już niemal wyłącznie wysoko przetworzone produkty, importując zboże). Wzmożona aktywność handlowa stała się przyczyną urbanizacji i rozwoju techniki, a jednak, jak uważa Meiksins Wood, nie gospodarki kapitalistycznej. Argument amerykańskiej historyczki opiera się według holenderskiego historyka Pepijna Brandona (Brandon 2011, 135-140) na dwóch twierdzeniach dotyczacych stosunków produkcji w Republice. Po pierwsze, produkcja rolna nie została tam tak jak w Anglii przekształcona w sposób, który sprawiałby, że produkcja środków utrzymania oraz dostęp do środków produkcji został zapośredniczony przez przymusowe uczestnictwo w wymianie rynkowej. Po drugie, holenderska klasa rządząca, kupiecka i finansowa elita, opierała swoją władzę oraz zdolność do przechwytywania społecznie wytworzonych nadwyżek 
na pozaekonomicznych formach panowania silnie związanych z przywilejami oraz pozycja w aparacie państwowym (tzw. arystokratyzacja czy „wtórna feudalizacja” elit). Oczywiście argumenty te są ściśle powiązane, gdyż bez nowych form kontroli społecznej produkcji w postaci ekonomicznej zależności i proletaryzacji nie ma nowych form organizacji pracy i vice versa.

Narastający w kraju konflikt dotyczący formy władzy oraz kwestii suwerenności, nie miał nic wspólnego z rozpadem feudalizmu czy demokratyzacja życia politycznego, rzekomo powiązanych z rozwojem kapitalizmu. Choć życie nie tylko elit, ale i niespotykanej do tej pory części społeczeństwa zależało od produkcji i wymiany rynkowej, to ani handel, ani produkcja w Republice nie opierały się na kapitalistycznych zasadach. Nie były one zależne od presji konkurencji na jednym rynku (tak jak działo się to w Anglii), lecz od dominującej pozycji w posegmentowanych rynkach (Meiksins Wood nazywa zyski z takiego rodzaju handlu, za Marksem, „zyskiem ze sprzedaży” (profit on alienation) czyli takim, który pochodzi z nieekwiwalentnej wymiany; por. Marks 1960, 7-17, Meiksins Wood 2002, 134-142, Meiksins Wood 2007): kontroli dróg handlowych, militarnej przewagi pozwalającej zwalczać konkurencję, przywilejów w wymianie, praktyk monopolistycznych, rozwoju specyficznych narzędzi finansowych oraz rozbudowania sieci militarno-handlowych placówek w strategicznych miejscach (Meiksins Wood 2012,113) 21. Taka forma handlu może być w dużej mierze kompatybilna z kapitalizmem, jednak sama nie ma kapitalistycznego charakteru. Z obecności tego typu działalności w kapitalizmie dobrze zdaje sprawę teoria systemówświatów, jednak jednocześnie utrudnia ona dostrzeżenie istotnych różnic między kapitałem w niekapitalistycznym społeczeństwie a społeczeństwem kapitalistycznym (często wskazuje się na powiązanie kapitału handlowego i finansowego Niderlandów z kapitałem przemysłowym Anglii, niejako wskazując na pośredni czy systemowy charakter kapitalizmu w regionie).

W przypadku Republiki jest to dominacja militarno-handlowa, rozwinięta później w kapitalizmie do niespotykanych wcześniej rozmiarów, jednak niezależnie od tego, jak głębokie byłoby to podobieństwo, nie sprawia ono jeszcze, żeby gospodarkę tę można rozpatrywać jako kapitalistyczną. Co więcej, Republika wcale nie rozwijała się w kierunku kapitalistycznym i jeszcze w osiemnastym wieku wzrastała w niej ilość rentierów oraz zaostrzała się rywalizacja o posady w państwowym aparacie, a rywalizacja militarno-handlowa z Francją prowadziła do zaangażowania się pod koniec siedemnastego wieku w wsparcie

21 Innym znakomitym przykładem jest absolutystyczna Francja, gdzie stawka gry politycznej dla klasy dominującej była nie (re)produkcja systemu pozyskiwania wartości dodatkowej, tylko maksymalizacja udziału w „scentralizowanej feudalnej rencie”, w której narzędziem pozyskiwania nadwyżek była administracja królewska i jej aparaty. Był to alternatywny dla kapitalizmu system, w którym, jak uznajeAntoine de Montchrétien (jeden z pierwszych teoretyków francuskiej ekonomii politycznej) to sam król, a nie mechanizmy rynkowe, stanowił centralny mechanizm regulujący i doprowadzający gospodarkę do równowagi (Meiksins Wood 2012, 166). 
Williama III jako kandydata na króla Anglii i zawarcie sojuszu przeciwko Francji. W operację tę były zaangażowane nie tylko fundusze wpływowych elit, ale fundusze i giełdy amsterdamskiej, a nawet niderlandzkie wojsko, okupujące przez pewien czas Londyn (Meiksins Wood 2012, 116). Stawką rozgrywki politycznej była najlepsza pozycja w grze o politycznie ukonstytuowaną własność, pozwalająca przechwytywać zyski ze sprzedaży. Taka forma gospodarki niekapitalistycznej była bezpośrednio powiązana z określoną formą władzy, nazywanej przez Meiksins Wood „politycznie konstytuowaną własnościa”, gdzie przywileje i stanowiska państwowe były źródłami dochodu bądź warunkami możliwości osiągania wysokich dochodów. W kraju, gdzie narastał badany przez Hugo Grocjusza, teoretyka imperialistycznych zapędów Republiki (autora pierwszej próby jurydycznego uzasadnienia takiej polityki w formie prawa międzynarodowego i naturalnego), czy później przez Spinozę, konflikt polityczny między monarchią i elitami republikańskimi, gdzie podobnie jak w Anglii nieoczekiwaną i niepokojącą teoretyków rolę zaczynała odgrywać wdzierająca się siłą do polityki wielość, gra polityczna niewiele miała wspólnego z kapitalistycznym sposobem produkcji. Aby dostrzec tę różnicę, trzeba cały czas mieć na uwadze, w jaki sposób produkowane są i przechwytywane nadwyżki. W tym przypadku, choć ma miejsce produkcja na rynek w kraju wysoko zurbanizowanym, gdzie bujnie rozwija się kultura i technika, gdzie jednak nie ma miejsca wytwarzanie wartości dodatkowej, a jedynie przechwytywanie nadwyżek. Radykalne przemiany polityczne mające miejsce w Zjednoczonych Prowincjach nie muszą mieć nic wspólnego z rozwojem kapitalizmu.

Charakter modernizacji Republiki Zjednoczonych Prowincji czy szerzej całych Niderlandów jest, od czasów Adama Smitha czy później Marksa po dziś dzień, przedmiotem gorącego sporu (Meiksins Wood 2007). Podstawowy podział dotyczy oczywiście kwestii, czy motorem przemian był rozwój handlu (jak w przypadku teorii Smitha, Wallersteina czy Giovanniego Arrighi) czy też przemiany w sferze produkcji (jak w przypadku teorii Maurice Dobba, Brennera czy Meiksins Wood) (Brandon 2011, 106-116). Nie chcąc powtarzać co do zasadniczych założeń i stawek omówionego już powyżej sporu między marksistami szkoły Brennera (w tym Meiksins Wood) oraz teoretykami zbiorczo określonymi jako przedstawiciele modelu handlowego, chciałbym uwypuklić teoretyczne znaczenie tego sporu. W tym celu pokrótce przedstawię spór między Brennerem i Meiksins Wood opisany przez amerykańskiego historyka Charlesa Posta oraz wnioski z krytyki przedstawionej przez Brandona.

Jak twierdzi Post w swoim artykule Comments on the Brenner-Wood Exchange on the Low Countries (Post 2002), Meiksins Wood krytykuje Brennera za zbyt łatwe (i w istocie sprzeniewierzające się własnym założeniom) przyjęcie znaku równości między komercjalizacją społeczeństwa niderlandzkiego i przejściem do kapitalizmu. Zdaniem Meiksins Wood moga istnieć niekapitalistyczne formy komercjalizacji, co więcej, mogą one być do pewnego stopnia kompatybilne z kapitalizmem. W swoim artykule Brandon nie zgadza się z obydwoma 
podstawowymi tezami Meiksins Wood dotyczącymi niekapitalistycznego rozwoju Niderlandów i wskazuje, że powstanie merkantylistycznego i finansowego kapitału zakładało przemiany w sferze produkcji, które stanowią dla niej warunki sine qua non rozwoju kapitalizmu (obala więc poniekąd wnioski Meiksins Wood, posługując się jednak jej założeniami). Niemniej jednak Brandon przyznaje jednocześnie, że tak potężny rozwój tych form kapitału w „złotym” siedemnastym wieku sprawił jednocześnie, że późniejsza zapaść gospodarcza oraz brak zainteresowania elit industrializacją wynikał z hamującego wpływu, jaki na rodzimy przemysł miał ten rozwój. Wbrew wyjaśnieniom komercjalizacyjnym twierdzi, że nawet w tak zurbanizowanym i zorientowanym na handel społeczeństwie nowe formy organizacji społecznej nie mogłyby się pojawić bez przemian społecznych w sferze produkcji ${ }^{22}$. Wbrew tezom Meiksins Wood twierdzi on także, że przecenia ona znaczenie kryzysu i zapaści w osiemnastym wieku, po którym Niderlandy, mając inny układ stosunków społecznych niż Anglia, rozwijały się jako kapitalistyczne społeczeństwo. Wskazuje on zatem, że Niderlandy, choć charakteryzowały się inną dynamiką rozwoju niż Anglia, wstąpiły już w omawianym okresie na drogę kapitalistycznego rozwoju. Jednocześnie zgadza się, że przykład Republiki Zjednoczonych Niderlandów stanowi przykład „nieudanego przejścia” czy zatrzymanego rozwoju. Rozwinięty handel i finanse raczej dusiły przez dłuższy czas rozwój przemysłu niż go pobudzały (gdyż oferowały drogę rozwoju prostszą i gwarantującą większe zyski niż rozwój kapitału przemysłowego). Niezależnie od oceny, czy opisane przez Meiksins Wood formy organizacji władzy stanowiły hamulec rozwoju kapitalizmu czy formę bezpośrednio poprzedzająca rozwój kapitalizmu i od naszej oceny wniosków Brandona, zasadniczo zbieżnych z tezami Meiksins Wood (podważającymi mocno tezę pierwszą, lecz w dużo mniejszym stopniu druga), można z tej debaty wyciagnać bardzo istotny wniosek. Rozwój Anglii stanowi historycznie pierwszy przypadek rozwoju gospodarki kapitalistycznej i sposób, w jaki sposób przemiany te zaszły, stanowi klucz do zrozumienia rozwoju kapitalizmu w innych krajach oraz rozwoju kapitalistycznego systemu w ogóle - właśnie dlatego, że pokazuje on powstanie społeczeństwa kapitalistycznego i jego głębokie przemiany na poziomie produkcji i reprodukcji społecznej. Jednak, jak słusznie podkreśla Brandon, nie oznacza to, że należy używać tego przykładu jako „typu idealnego”, przez porównanie z którym inne kraje sa oceniane jako realizujące ten sam model rozwoju lub nie. Zresztą taka wulgarna interpretacja znaczenia przykładu Anglii dla politycznego marksizmu wydaje się mało przekonująca. Różnica

22 Organizacje handlowe i finansowe mogą być zarówno motorem rozwoju, jak go hamować, a także, jak dowodzi przypadek imperium arabskiego czy, przynajmniej do pewnego momentu, imperium holenderskiego, w ogóle nie musi mieć nic wspólnego z kapitalizmem (Meiksins Wood 2005, 44-72). Formy organizacji handlu i finansów sama w sobie nie są nośnikiem żadnych nowoczesnych czy kapitalistycznych relacji, choć oczywiście mogą być i stają się nimi w kapitalizmie. Pytanie, na ile mogą na powrót stracić tę funkcję w abstrakcyjnym ruchu, w którym realna kontrola nad społecznym procesem produkcji staje się coraz bardziej zapośredniczona przez abstrakcyjną własność, oderwaną i odrywająca od kontroli, stanowi istotny temat dotyczącej porządku następującego po kapitalizmie refleksji w III tomie Kapitału (Marks 1984, 677-685). 
między Meiksins Wood a Brandonem dotyczy oceny znaczenia funkcji handlu i finansów dla rozwoju regionu. Niemniej jednak istnieje zupełna zgoda, że były one czynnikami hamującymi czy znacznie spowalniającymi rozwój kapitalizmu. Istotny potencjał tej teorii tkwi w wysiłku stworzenia kryterium pozwalającego na rozróżnianie kapitalistycznych stosunków produkcji od niekapitalistycznych form organizacji społecznej i zrozumienie wzajemnego powiązania tego typu form. Jeszcze ważniejsze jest chyba rozumienie, że kapitał ma różne formy i że ich znaczenie jest zależne od ich funkcji w społecznym procesie produkcji.

II.

\section{Klasa jako proces}

Ponieważ jest to pierwszy w języku polskim tekst poświęcony twórczości Meiksins Wood, ograniczę prezentację jej poglądów dotyczących klasy do dwóch zagadnień: różnicy między ujmowaniem klasy jako struktury i jako procesu oraz krótkiej prezentacji pojęcia „społecznych stosunków własności” czy też „stosunków reprodukcji” jako próby ukazania wielowymiarowości procesów zarówno formowania się klas jak i walki klasowej.

W eseju Class as process and relationship (Meiksins Wood 2016, 78-91) Meiksins Wood wyróżnia dwa rozumienia pojęcia klasy: strukturalne oraz relacyjne (w marksizmie pojęcia te dotyczą przede wszystkim stosunków produkcji, choć teoretyczka takie wąskie podejście wielokrotnie krytykowała). Do strukturalnych definicji możemy zaliczyć zarówno te liberalne, opierające się na wysokości dochodu (z typowym mglistym pojęciem klasy średniej), jak wiele propozycji postmarksistowskich (np. łączących poststrukturalną psychoanalizę z marksizmem), lecz i marksistowską dogmę, z jej strukturalną metaforą bazy i nadbudowy. Zdaniem Meiksins Wood poststrukturalizm i postmarksizm czy kulturalizm łączy określona forma rozumienia klasy, w którym istnieje element zmienny i niezmienny. Niezmiennik stanowi bądź podstawę badań i diagnoz, bądź transcendentalną płaszczyznę dostępu do zjawisk społecznych, np. wyjaśniania zjawisk przez ich relację do gospodarki albo do sfery kultury. Struktura klasowa jest zatem efektem działania niezmiennika determinującego $\mathrm{w}$ ten lub inny sposób charakter społeczeństwa - rolę niezmiennika może tu pełnić np. struktura gospodarki czy hegemoniczna forma kultury (Meiksins Wood 2016, 51-56).

Klasycznym przykładem tego typu myślenia jest heglowskiej proweniencji schemat, w którym niezmiennikiem jest pojęcie świadomości: przejścia od „klasy w sobie” (pozycja w strukturze społecznej) do „klasy dla siebie” (proces stawania się świadomym i aktywnym podmiotem historycznym), którym posługiwał się sam Marks. Chodzi tu o przejście od pozycji w obiektywnej strukturze (posiadania środków produkcji czy bycia pracownikiem najemnym ich pozbawionym) do świadomego i aktywnego kształtowania tejże pozycji, prowadzącego 
ostatecznie do zniesienia samej klasowej struktury. Nie wnikając w debatę nad znaczeniem tej pary pojęciowej poprzestanę na twierdzeniu, że za jego pomocą stawia się istotny problem, lecz oczywiście niemożliwe jest osiagnięcie jakiegokolwiek jego rozwiązania, gdyż powiązanie tych dwóch zjawisk odbywa się na gruncie normatywnym (takie jest „przeznaczenie” klasy pracującej czy logika ruchu jego idei), a nie opisowym.

Marksistowskie rozumienie tego, czym jest klasa może być przedstawione w kategoriach niezmiennika struktury bardzo często określanej jako „obiektywna” oraz procesu stawania się klasy pracującej (czy klas w ogóle) w formie doświadczenia jako czegoś „subiektywnego”.

Według Meiksins Wood, podążającej śladem brytyjskiego historyka E.P. Thompsona, należy przeformułować ten problem uznając, że zawsze mamy do czynienia tylko i wyłącznie z ustrukturyzowanymi procesami historycznymi. Oznacza to, że należy zredefiniować pojęcia obiektywnej struktury klasowej, jak i stawania się klasy (proces, który Meiksins Wood nazywa formowania się klasy). Zastana sytuacja klasowego charakteru społeczeństwa i specyficznego dla niego charakteru relacji między klasami strukturyzuje doświadczenie podmiotów żyjących i działających w tymże społeczeństwie. Wraz z mityczną preegzystencją kapitalizmu znika też mityczna preegzystencja klas kapitalistycznego społeczeństwa. Zawsze mamy do czynienia z procesami przemian społeczeństw ludzkich, które są w określony sposób ustrukturyzowane - sposób produkcji jest tego typu strukturalnym określeniem. Tak samo dla społeczeństwa kapitalistycznego pewna określona struktura społeczna - klasowy podział - jest wynikiem ścierania się interesów klas. Kształtowanie się tych interesów i formowanie się klas nie ma podstawy w jakiejś niezmiennej czy „dominującej” sferze czy części struktury społecznej, a raczej przenika wszelkie możliwe sfery życia społecznego: kulturę, produkcję, konsumpcję, waloryzację itd. W tym też sensie klasa pracująca to oczywiście nie pracownicy określonej podstawowej sfery, ale szereg różnych grup zajmujących określone pozycje w uspołecznionym procesie produkcji (czy patrząc szerzej - coś, na co Marks był w dużej mierze ślepy - procesie reprodukcji społecznej). W konsekwencji, jak sądzę, najtrafniej można by było określić podejście Meiksins Wood przez stwierdzenie, że o ile podstawowa charakterystyka kapitalistycznego sposobu - czy też, jak czasem pisze również Marks, procesu - produkcji nie stanowi żadnej tajemnicy już od czasów Marksa (a po części już od czasów klasycznej ekonomii), jednak określonego kształtu struktury tego procesu, zarówno w poszczególnych krajach czy regionach, jak i globalnie, nie sposób określić jako czegoś niezmiennego. Jest to niemożliwe w podwójnym sensie: historycznym, bo struktura jest tylko częścią zmiennego procesu przemian społecznych (w kapitalizmie bardzo dynamicznych), oraz ponieważ nie ma niezmiennych (w sensie: podstawowych) sfer życia społecznego, których opis czy opanowanie gwarantuje zrozumienie czy opanowanie całego społeczeństwa.

Aby zrozumieć różnicę między tymi podejściami, należy przyjrzeć się problemowi „braku” świadomości klasowej czy też braku procesów społecznych definiowanych explicite 
w klasowych kategoriach (np. jako „robotnicze”) - czyli braku niezmiennej sfery czy podstawy struktury kapitalistycznej. Pojawianie się form organizacji czy eksplikacji interesu w postaci „świadomości klasowej”, czyli ze względu na pozycję w abstrakcyjnie ujętej strukturze kapitalistycznego sposobu produkcji, jest niezwykle rzadkie. W konsekwencji „nieobecność” świadomości klasowej w postaci dominacji strategii osobistego rozwoju i konkurencji wśród robotników, czy też zawsz̧e partykularnych form organizowania się jako kobiety, czarni, pracownicy poczty, Polki itd., jest zawsze sytuacją zrozumiałą i taką, od której musi się zacząć analiza klasowa, a nie wyjątkiem czy dowodem na nieobecność klas. Jednocześnie należy pamiętać, że choć formowanie się klasy ma zawsze partykularny charakter, nie oznacza to, że charakterystyka ta nie poddaje się uniwersalizacji i że te partykularne formy organizacji nie maja charakteru klasowego. Aby lepiej zrozumieć proces formowania się klasy i zagadkę nieobecności owej „świadomości klasowej”, przyjrzyjmy się temu, w jaki sposób kapitaliści ingerują w formowanie się klasy pracującej.

Jak klarownie przedstawia to w swoim tekście Rescuing Class From the Cultural Turn Vivek Chibber (Chibber 2017), proces uniwersalizacji specyficznych dla kapitalizmu relacji społecznych ma charakter negatywnej selekcji - przymusowy charakter klasowego podziału społeczeństwa sprawia, że odrzucone zostaja jedynie te partykularne tożsamości, dażzenia czy działania, które są z nim niezgodne (co jest zgodne, a co nie pozostaje zresztą zwykle przedmiotem negocjacji). W związku z tym, o ile zostaną spełnione określone kryteria, każdy typ stosunków społecznych czy tożsamości może zostać zaakceptowany: może ulec komodyfikacji, stać się narzędziem podporządkowania czy źródłem samoorganizacji. Z tego zdania należy wyciagnąć dwie istotne konsekwencje. Po pierwsze, kapitalistyczny sposób produkcji nie wymaga, by wszystkie stosunki społeczne były podporządkowane jego wymogom - podporządkowane muszą być tylko te, które stoją z nim w jakiś sposób w sprzeczności (np. ograniczaja zyski czy stanowia polityczną przeszkodę dla procesu akumulacji). W tym sensie kultury określonych grup etnicznych czy subkultury niekompatybilne z kapitalistycznym sposobem produkcji nigdy nie doświadczaja anihilacji, a właśnie procesu formowania i uzgadniania z wymogami kapitalizmu. Po drugie, takie rozumienie procesów formowania się klasy pozwala nam zrozumieć w kategoriach klasowych wszystkie te procesy, które nie maja jawnie i celowo klasowego charakteru, a także odrzucić idealistyczny z natury problem odnalezienia modelowej „prawdziwej” klasy pracującej (oraz rewers tych poszukiwań, czyli odrzucenie teorii marksistowskiej z powodu braku możliwości odnalezienia takiego ideału). „Brak” świadomości nie jest wynikiem „nieświadomości” czy „niezrozumienia” (to raczej przesąd intelektualistów) dla sfery fundamentalnej czy niezmiennej, czy to gospodarki, czy hegemonii kulturowej burżuazji, a właśnie prostą konsekwencją braku takiej sfery - mnogości sfer czy aspektów życia członków społeczeństwa kapitalistycznego odpowiada mnogość procesów społecznych. Wszystkie aspekty życia dają się wpisać w proces akumulacji kapitału, 
niemniej jednak właśnie sposób w jaki to się dzieje ma zupełnie kluczowe znaczenie i, co niezwykle ważne, klasowy charakter.

Formowanie się klas należy rozumieć zarówno jako relacje między klasami (wertykalne) jak i relacje między członkami tej samej klasy (horyzontalne). Klasy są formowane zarówno przez wzajemne oddziaływanie, jak i przez oddziaływania w obrębie samej klasy. W tym sensie, jak podkreśla Meiksins Wood, w marksizmie politycznym olbrzymi nacisk położony jest na konkurencję i kooperację w obrębie klas, przez co zjawiska „niewidzialnych” klas czy „,niewidzianej” walki klasowej („walka klas bez klas”, jak określał to zjawisko w prowokacyjny sposób E.P. Thompson) stają się możliwe do teoretycznego ujęcia, co niezwykle wzbogaca marksistowskie analizy i uzupełnia głęboką ślepotę marksizmu na problemy trudne do sproblematyzowania w kategoriach wertykalnych relacji między klasami (Meiksins Wood 1999). Dla wulgarnego marksizmu istnieją tylko wertykalne relacje między abstrakcyjnymi klasami kapitalistów i robotników. W marksizmie politycznym walka klas zwykle odbywa się na płaszczyznach horyzontalnych, powiązanych wertykalnie w złożony sposób - jednak, co istotne, połączenia te strukturyzują relacje klasowe (zwykle nazywane w marksizmie stosunkami produkcji).

Z tych kompleksowych relacji, sieci konfliktów i sojuszów, ma zdawać sprawę opracowane przez Brennera pojęcie „społecznych stosunków własności” czy „stosunków reprodukcji”. O ile Brenner zastosował to pojęcie na dość wysokim poziomie ogólności w toku debaty o przejściu z feudalizmu do kapitalizmu, to Meiksins Wood dokonała głębokiej pracy nie tylko badawczej, ale i interpretacyjnej, pozwalającej zrozumieć to złożone pojęcie i nadać mu treść i znaczenie. Dotyczy to w szczególności jego najbardziej kontrowersyjnego aspektu, czyli horyzontalnych stosunków między członkami poszczególnych klas.

Zdaniem Meiksins Wood nie należy upierać się, że wszelkie mechanizmy rynkowe sprowadzają się do takich czy innych form wyzysku czy politycznej i ideologicznej kontroli (stosunków wertykalnych np. kapitalista-robotnik), choć sama zawsze podkreśla, że dla zrozumienia specyfiki kapitalizmu trzeba wyjaśnić, jak urynkowienie może stanowić przymus, a nie pewną mo:̇liwość. Przymus ten ma jednak relatywny, a nie absolutny charakter.

Demokracja liberalna jest gwarantem określonej sfery wolności o tyle, o ile wolność ta nie wchodzi w konflikt $z$ relatywnym przymusem (czy raczej grupa imperatywów akumulacji kapitalistycznej) niezbędnym dla akumulacji kapitału ${ }^{23}$. Przywołując określenie Chibbera, owa „negatywna selekcja” sprawia, że poza granice tolerancji odsiane zostaje tylko to, co zbyt mocno lub bezpośrednio uderza w podstawy kapitalizmu. Oczywiście te mechanizmy dopasowania i selekcji stanowią negatywną podstawę klasowego charakteru społeczeństwa

\footnotetext{
23 Przymus absolutny byłby totalnym podporządkowaniem życia jako celu samego w sobie - co oczywiście jest niezgodne z jednym z fundamentalnych określeń kapitalizmu maksymalizacji zysków i minimalizacji kosztów, gdyż nadmiarowa kontrola jest nierentowna, nie generuje zysków.
} 
kapitalistycznego: określają, co muszq robić przedstawiciele danej klasy, by nimi w ogóle być. Tym samym zmuszeni są do przestrzegania określonych reguł reprodukcji społecznej - to, jakim regułom podlega nasze życie, określa naszą przynależność klasową. Niemniej jednak realizacja tego przymusu i stosunek do niego nie musi już wcale mieć ściśle określonego charakteru ani ogniskować się ,jawnie” wokół konfliktu klasowego. Jak argumentuje Meiksins Wood, absolutny przymus jako naga polityczno-militarna dominacja klasowa oparta tylko na sile, funkcjonująca jako narzędzie pozyskiwania nadwyżek od producentów jest dokładnie tym co w kapitalizmie nie występuje. Występuje natomiast przymus relatywny, wywierany zarówno przez klasę do której przynależymy, jak i klasę przeciwna. Formowanie się klasy jest dla Meiksins Wood procesem wielowymiarowym zarówno ze względu na szereg możliwych interakcji między klasami i w ich obrębie, jak i ze względu na mnogość sfer życia społecznego, które są jego składowymi.

\section{Demokracja i obywatelstwo}

We wstępie do Citizens to Lords Meiksins Wood identyfikuje amerykański neokonserwatyzm Leo Straussa oraz szkołę historyków z Cambridge (Cambridge School) jako próby zawłaszczenia pojęć „demokracji” i „obywatelstwa” przez konserwatystów, dla których badania nad antyczną demokracja jako ustrojem opartym na niewolnictwie, sa uzasadnieniem pesymizmu wobec równości i sprawiedliwości społecznej, elitaryzmu i dodatniego wartościowania nierówności społecznych. Konserwatystom udaje się zbudować pewną analogię co do niezmienności fundamentalnych struktur demokracji, w tym strukturalnej nierówności jako cechy niezmiennej i immanentnej dla demokracji. W Peasant-Citizen and Slave Meiksins Wood argumentuje, że od osiemnastego wieku w liberalnych i konserwatywnych teoriach (Monteskiusz, Smith, Ferguson, Hegel), stawką staje się udowodnienie na podstawie badań historycznych antycznych społeczeństw, że kompetencje polityczne są związane z wolnością od pracy. Zarówno demokracja ateńska, jak i późniejsze ustroje sa rozważane zawsze jako pewien układ elit, w którym stale istnieje ryzyko interwencji ludu (demos, plebsu, wielości, chłopstwa, motłochu). Rola ludu ogranicza się w nich do pewnych „zakulisowych działań”, aklamacji poczynań elit, sporadycznych i pozbawionych większego znaczenia interwencji w sferę polityki itd. Jest to według Meiksins Wood tzw. „mit leniwego tłumu” (the Myth of the Idle Mob), w którym sfera polityki jest zawsze przeciwstawna sferze pracy, a interwencja pracowników czy producentów w sferę polityki rozumiana jest jako ich wyjście poza swoją naturalna rolę: wyraz impulsywnego wybuchu gniewu czy lenistwa i nieuzasadnionych roszczeń (Meiksins Wood 2015a). Historyczka stara się uchwycić w swych pracach tendencje demokratyczne w Grecji czy Rzymie jako pewien wyjątkowy proces wzrostu mocy politycznej producentów (w greckim polis przede wszystkim rolników-obywateli), przeciwstawiających się despotyzmowi oraz oligarchii oraz 
jako pewien proces formowania się nowej klasy wchodzącej w konflikt z dotychczasowymi stosunkami społecznymi, odpierając tym samym próby konserwatywnego zawłaszczenia historii.

Przykładowo, spór o ustroje polityczne w Atenach i o znaczenie demokracji powinien być rozumiany w kontekście całego życia społecznego polis (Meiksins Wood 2016, 181-204), jako część walki klasowej, której płaszczyzna wymyka się tradycyjnym porządkom i klasyfikacjom pojęciowym. Demokrację Ateńską należy postrzegać nie jako wyłonienie się czystej sfery polityki, a jako serię przesunięć i zwycięstw nowej, egalitarnej metody uprawiania polityki i rządzenia (przede wszystkim jako proces historyczny, a nie określoną strukturę). Próbując zmapować krótko ten proces, możemy wyróżnić parę takich przesunięć tendencji demokratycznej w ateńskiej polis: a) reformy Solona - oddłużenie chłopów pozbawia arystokrację ważnego narzędzia dominacji, b) ludowy organ parlamentarny - pojawienie się obok ludowego areopagu organu parlamentarno-sądowniczego „rady czterystu”, c) formowanie się tożsamości opartej na prawach obywatelskich - reforma administracyjna prowadzi do zmiany organów władzy i tożsamości z klanowo-rodowej na identyfikację obywatelską ze wspólnotą polityczną, określoną regionalnie ${ }^{24}$, d) sekularyzacja i demokratyzacja władzy jurydycznej - pojęcie o konotacjach religijnych thesmos zastępuje nomos, związane z prawem zwyczajowym.

Dla Meiksins Wood analiza stosunków politycznych wiąże się z procesem przechwytywania nadwyżek, w antycznej Grecji tworzonych przede wszystkim przez rolników, gdzie obywatelstwo staje się polityczną gwarancją wpływu producentów na reguły działania tego procesu, czyli właśnie ugruntowania swojej władzy politycznej w kontroli procesu produkcji (Meiksins Wood 2008, 30-37). Teoria polityczna Platona i Arystotelesa powstaje już w reakcji do tego procesu (nie sa oni myślicielami reprezentatywnymi dla epoki), a stawka polityczną jest przeciwstawienie się tendencji demokratycznej (metafizyczna bądź naturalistyczna argumentacja na rzecz politycznej nierówności ludzi). Stąd też poglądy Platona czy Arystotelesa są w dwudziestym wieku przytaczane na rzecz argumentacji za nierównością ludzi wobec panowania demokracji i przynajmniej formalnej równości. Analogia jest tutaj budowana ze względu na samą konieczność ustosunkowania się do demokracji (np. możliwości wyłomu w niedemokratycznym sposobie organizacji produkcji), problemu bycia postawionym wobec mocy produkcyjnej i politycznej wielości, czy ludu. Niemniej jednak, jak podkreśla Meiksins Wood, to, jakie znaczenie ma obywatelstwo, jest nierozerwalnie związane z procesem produkcji w danym społeczeństwie. Obywatelstwo w ateńskiej polis ma bezpośrednie znaczenie ekonomiczne, chroniąc obywateli przed taką formą pozyskiwania nadwyżek jak poddaństwo. Natomiast obywatelstwo pojmowane tak, jak definiował je nowożytny liberalizm, podobnie

\footnotetext{
24 Obywatele zaczęli identyfikować się swoim demotikonem, czyli symbolem demu, w którym żyli, a nie nazwa klanu czy rodu (Meiksins Wood 2008, 38).
} 
chroni przed analogiczną formą przymusu - jednak w czasach, gdy nie gra już ona istotnej roli. Liberalne pojęcie wolności paradoksalnie opiera się na przednowoczesnych stosunkach społecznych, gwarantując wolność od czegoś, co nie jest już istotne i tworząc ramy prawnoteoretyczne dla przymusu pracy (Meiksins Wood 2016, 233)²5. Teoretyczka podkreśla, że grając na tej różnicy, osiaga się dwie rzeczy jednocześnie: dewaluuje się demokrację jako radykalny projekt władzy klasy pracującej (ludu, narodu, „zwykłego człowieka”, obywatela itd.), oraz dowartościowuje się oligarchiczne rządy klasy posiadającej, budując złudną analogię pomiędzy obywatelstwem w polis a pozycją oligarchicznych elit liberalnej demokracji. Problem różnicy ekonomicznego znaczenia obywatelstwa w obrębie różnych sposobów produkcji jest w konserwatywnej narracji odwracany lub niwelowany przez zignorowanie różnic i wskazanie domniemanego podobieństwa między nimi: demokracja opiera się zawsze na wyzysku, a więc jest on poniekąd usprawiedliwiony, stanowi on „cenę wolności”. W tym zrównaniu przekreślone zostaje to, że w Atenach równość prawna miała swoje podstawy w równości ekonomicznej, a pojawienie się demokracji było procesem, który pojawił się wbrew nierównościom (tutaj centralnym problemem jest oczywiście istnienie i znaczenie niewolnictwa w antycznej Grecji i tego, na ile demokracja była kontrtendencja dla rozrostu niewolnictwa, a na ile tendencję tę mogła wzmacniać). Meiksins Wood konkluduje, że niedostępność czy unikalność dóbr politycznych została w kapitalizmie zniesiona przez ich dewaluację i powiązanie wyzysku ze sferą ekonomiczną (nie zaś polityczna); za sprawą tej dewaluacji dokonuje się jednocześnie separacja polityki i ekonomii (Meiksins Wood 2016, 275-276). Analiza pojęcia demokracji jest zatem, w wydaniu amerykańskiej historyczki, zawsze analizą klasowa, a zatem opierającą się na założeniu, że nie możemy zrozumieć, czym była demokracja w danym społeczeństwie, bez analizy stosunków produkcji. W Democracy against Capitalism podkreśla ona, że w związku z tym demokracja zawsze jest naznaczona panującymi stosunkami władzy, a jej rozumienie jest perspektywiczne. Pozostaje to szczególnie istotne, gdy analizuje się koncepcje ciążące ku demokratycznej władzy elit w okresie „zagrożenia” radykalną demokracja, takie jak koncepcje Platona i Arystotelesa, klasycznych republikanów brytyjskich (Harrington, Sidney, Neville), czy oczywiście klasyków liberalizmu takich jak John Locke, będący ideologiem nowej klasy panującej (ludzi takich jak jego patron - kapitalista wczesnego kapitalizmu par excellence, Anthony Ashley Cooper). Tak, jak demokracja w antycznej Grecji była procesem społecznym, który nie zrodził się w próżni, tak też demokracja w kapitalizmie $z$ definicji jest ograniczona separacja mocy produkcyjnej podporządkowanej kapitałowi i politycznych warunków funkcjonowania społeczeństwa. Status ekonomiczny nie jest

\footnotetext{
25 Oczywiście paradoks ten nabiera jasnego znaczenia, gdy rozumiemy owe prawa obywatelskie w sposób negatywny: jako dystrybucję nierówności (na tle klasowym, rasowym, genderowym itd.). Sens bycia obywatelem jest określony przede wszystkim przez relację do tych, którzy są pozbawieni praw: kobiet i dzieci, ludności zamieszkującej kolonie i wszystkich określanych mianem motłochu czy wielości.
} 
kryterium obywatelstwa, ale obywatelstwo nie gwarantuje praw, które zrównywałyby obywateli ekonomicznie. Niemniej jednak, jak twierdzi autorka Democracy against Capitalism, to, że w społeczeństwie kapitalistycznym możliwa jest demokracja, wynika nie z faktu, iż produkcja kapitalistyczna jest warunkiem politycznej demokracji, ale z tego, że warunkiem produkcji kapitalistycznej jest podporządkowanie życia społecznego, przede wszystkim realizacji potrzeb, procesowi akumulacji kapitalistycznej. Jak podkreślałem już w części poświęconej pojęciu klasy, podporządkowanie to ma jedynie relatywny charakter, działając wybiórczo i negatywnie, stąd też kapitalizm stanowi fundamentalne i realne ograniczenie, a nie podstawę demokracji.

\section{Zakończenie}

Przedstawiona w części pierwszej debata o początkach kapitalizmu w Anglii jest z pewnością najważniejszym sporem, z którego wyłoniło się stanowisko Meiksins Wood i Brennera. Stojące w centrum ich badań, przepracowane pojęcie „sposobu produkcji”, w którym sprzęgnięta zostaje analiza historyczna społeczeństwa i gospodarki, bardziej niż do technologicznego determinizmu prowadzi do konkluzji, że pierwszym produktem kapitalistycznego sposobu produkcji jest społeczeństwo kapitalistyczne, a pierwszym wynalazkiem kapitalistycznej produkcji nie jest maszyna parowa, tylko upowszechnienie pracy najemnej jako formy organizacji społecznej. Jednocześnie, jak wskazałem na przykładzie badań nad kapitałem handlowym w istniejącej między szesnastym i osiemnastym wiekiem Republice Zjednoczonych Prowincji Niderlandzkich, sam kapitał może nie opierać się jeszcze w tym okresie na kapitalistycznym sposobie produkcji, a na specyficznej formie politycznie ukonstytuowanej własności (przez co, jak twierdzi Meiksins Wood, w ogólnie nie można tu było mówić o rozwoju kapitalizmu, a zdaniem Brandona należy mówić o „zahamowanym rozwoju”). Zysk w tym przypadku nie wynika z powiązania procesu pracy i życia robotników z kapitałem, a z nieekwiwalentnej wymiany, siły militarnej i przywileju. Tak rozumiany kapitał handlowy może oczywiście istnieć i w kapitalizmie, jednak jego charakterystyka nie oddaje specyfiki kapitalizmu jako sposobu produkcji, w której reprodukcja społeczeństwa zostaje trwale powiązana z procesem akumulacji kapitalistycznej. Dopiero to powiązanie go ze zmiana sposobu produkcji i w konsekwencji reprodukcji społecznej sprawia - jak wskazywał Brandon -że zaczyna pełnić określone funkcje. Podobnie kapitał w epoce kolonializmu i epoce postkolonialnej może wchodzić do krajów mniej rozwiniętych przynosząc fantomowa nowoczesność, wyspową modernizację i formalne podporządkowanie - pełniąc zupełnie inne funkcje niż w krajach centrum. Rozważania Meiksins Wood nasuwają ciekawe pytania o zależność procesu reprodukcji społecznej i akumulacji kapitału: w jakim stopniu typ i stopnień podporządkowania kapitałowi wpływa na charakter społeczeństwa, w którym się rozwija. Przedstawiona w części drugiej debata dotycząca pojęcia „klasy” jako procesu i/lub 
struktury oraz roli pojęcia „demokracji” wskazuje, jak wielkie polityczne znaczenie maja rozstrzygnięcia co do sensu i znaczenia procesów historycznych. Klasowa analiza społeczeństw, wiążąca organizację polityczną z organizacją produkcji, określa je jako zawsze niestabilne i antagonistyczne procesy społeczne, pozostajace $\mathrm{w}$ pewnych formalnych zależnościach strukturalnych. Dając pierwszeństwo historycznym procesom „stawania się”, Meiksins Wood chce z jednej strony uniknąć pisania historii chłopów czy robotników jako strukturalnych „dopełnień” klas dominujących, jako „biernych i niemych widzów” dziejów, a z drugiej usunać z wyjaśnień historycznych element teleologiczny, mający zawsze ściśle ideologiczny charakter. Wbrew konserwatywnej narracji, jakoby warunkiem możliwości elementarnej spójności społeczeństwa była fundamentalna niespójność i nierówność (warunkiem praw obywatelskich wyzysk ekonomiczny, warunkiem równości obywateli istnienie suwerena będącego ponad prawem), można wykazać, że takie powiązanie procesów ekonomicznych i politycznych ma niekonieczny i historycznie określony charakter. Możemy sobie wyobrazić zarówno spójne społeczeństwo równych, jak i społeczeństwo skrajnych nierówności, pozbawione zupełnie spójności - jedno i drugie może nawet współistnieć, jako formalnie niekompatybilne, lecz realnie powiązane tendencje historyczne w obrębie jednego społeczeństwa. Demokracja, zarówno w antycznej Grecji jak i w dwudziestowiecznym kapitalizmie, jawi się w ujęciu Meiksins Wood jako pewna szansa, którą można pochwycić, obietnica społeczeństwa równych, właśnie dlatego możliwa w społeczeństwie klasowym, że sama z siebie niekonieczna, przekraczająca granice wyznaczone przez to społeczeństwo (to, co stanowi praymus kapitalistycznego społeczeństwa) poprzez bazowanie na jego możliwościach.

Bogata spuścizna nieżyjącej już Meiksins Wood nie ogranicza się do szeregu cenionych i do dziś wznawianych książek. Zostawiła ona po sobie całe pokolenie badaczy tworzących zgodnie z założeniami politycznego marksizmu bądź mocno się nimi inspirującymi. Do pokolenia tego należą autorzy tacy jak Charlie Post, autor The American Road to Capitalism Studies in Class-Structure, Economic Development and Political Conflict, 1620-1877, Spencer Dimmok, autor The Origin of capitalism in England, 1400-1600, Benno Teschke, który opracował niezwykle ambitny projekt marksistowskiej teorii stosunków międzynarodowych w pracy The Myth of 1648 Class, Geopolitics, and the Making of Modern International Relations, czy w mniej bezpośredni sposób, jednak głęboko z szkoła związany Vivek Chibber, którego praca Postcolonial Theory and the Specter of Capital odbiła się szerokim echem w debatach akademickich. 


\section{Wykaz literatury}

Anievas, Alexander i Kerem Nisancioglu. 2014. „The poverty of Political Marxism” International Socialist Review 94.

Aston, Trevor i Charles Philpin. 1985. The Brenner debate: agrarian class structure and economic development in pre-industrial Europe. Cambridge: Cambridge University Press.

Balibar, Étienne. 2009. Spinoza i polityka. Tłum. A. Staroń. Warszawa: Wydawnictwo Naukowe PWN.

Baran, Paul i Paul Marlor Sweezy. 1968. Kapitat monopolistyczny: szkice o amerykańskim systemie gospodarczym $i$ społecznym. Tłum. S. Łypacewicz. Warszawa: Państwowe Wydawnictwo Ekonomiczne.

Birch, Jonah, i Paul Heideman. 2013. „In defense of Political Marxism”. International Socialist Review 90.

Bonefeld, Werner. 2001. „The Permanence of Primitive Accumulation: Commodity Fetishism and Social Constitution". The Commoner 2.

Brandon P. 2011. „Marxism and the »dutch miracle«: The dutch republic and the transitiondebate". Historical Materialism. 19 (3): 106-146.

Brenner, Robert i Chris Harman. 2006. „The origins of capitalism”. https://www.marxists.org/archive/harman/2006/xx/wbrenner.htm.

Brenner, Robert. 1976. „, Agrarian Class Structure and Economic Development in PreIndustrial Europe". Past and Present 70.

Brenner, Robert. 1995. „The origins of capitalist development: a critique of neo-Smithian Marxism". W Development Studies: an Introduction Through Selected Readings, red. Ron Ayres. London: Greenwich University Press.

Brenner, Robert. 2007. Property and progress: Where Adam Smith Went Wrong. W Marxist Historywriting for the Twenty-first Century, red. Chris Wickham. Oxford: British Academy.

Callinicos, Alex. 1990. „, The Limits of „Political Marxism”. New Left Review:110-115.

Callinicos, Alex. 2016. „Marxism loses a passionate champion” http://socialistreview.org.uk/410/marxism-loses-passionate-champion.

Chibber, Vivek. 2016. „Remembering Ellen Meiksins Wood” https://www.jacobinmag.com/2016/01/ellen-Meiksins Wood-obituary-chibberretreat-from-class-origins-of-capitalism-marxist/.

Chibber, Vivek. 2017. „Rescuing Class From the Cultural Turn”. Catalyst 1 no. 1. https://catalyst-journal.com/vol1/no1/cultural-turn-vivek-chibber.

Davidson Neil. 2013. „Is there anything to defend in Political Marxism?”. International Socialist Review 91.

De Angelis, Massimo. 2001. „Marx and primitive accumulation: The continuous character of capital's »enclosures«". The Commoner 2.

Denemark, Robert i Kenneth Thomas. 1988. „The Brenner-Wallerstein Debate”. International Studies Quarterly 32(1): 47. 
Dimmock, Spencer. 2015. The origin of capitalism in England, 1400-1600. Chicago: Haymarket.

Engels, Frederyk i Karol Marks. 1984. Kapitał Tom 3. Warszawa: Książka i Wiedza.

F. Ilkowski. 2015. „Ellen Meiksins Wood - globalne imperium kapitału”. W tegoż, Imperializm kapitalistyczny we wspótczesnych ujęciach teoretycznych. Toruń: Wydawnictwo Adam Marszałek.

Heinrich, Michael. 2012. An Introduction to the Three Volumes of Karl Marx's Capital. New York: Monthly Review Press.

Holloway, John. 2017. „Przeczytajmy Kapitał - pierwsze zdanie. Albo Kapitał zaczyna się od bogactwa, a nie towaru". Tłum. Jakub Krzeski i Anna Piekarska. Praktyka Teoretyczna 3 (25): 22-45.

Linebaugh, Peter. 2008. The Magna Carta Manifesto. Berkeley: University of California Press.

Linebaugh, Peter. 2014. Stop, Thief! The Commons, Enclosures, and Resistance. Oakland: PM Press.

Marks, Karol. 1968. „Kapitał: Krytyka ekonomii politycznej. Księga I: Proces wytwarzania kapitału”. Tłum. Paweł Hoffman, Bronisław Minc, Edward Lipiński. W Marks, Engels, Drieta. T. 23. Warszawa: Książka i Wiedza.

Marks, Karol. 1982. „Kapitał: Krytyka ekonomii politycznej. Księga III: Proces produkcji kapitalistycznej jako całość". Tłum. Edward Lipiński, Julian Maliniak. W Marks, Engels, Džieta. T. 25. Cz. 2. Warszawa: Książka i Wiedza.

Marks, Karol. 1984. „Kapitał: Krytyka ekonomii politycznej. Księga III: Proces produkcji kapitalistycznej jako całość". Tłum. Edward Lipiński, Julian Maliniak. W Marks, Engels, Drieła. T. 25. Cz. 1. Warszawa: Książka i Wiedza.

Meiksins Wood, E. 1999. „Horizontal Relations: A Note on Brenner's Heresy”. Historical Materialism (4): 171-180.

Meiksins Wood, Ellen i Jim Stanford. 2013. „The Myth of Canadian Exceptionalism: Crisis, Non-Recovery and Austerity". Alternate Routes 24.

Meiksins Wood, Ellen. 1972. Mind and politics: an approach to the meaning of liberal and socialist individualism. Berkeley: University of California Press.

Meiksins Wood, Ellen. 1996. „Capitalism, Merchants and Bourgeois Revolution: Reflections on the Brenner Debate and its Sequel". International Review of Social History 41(2): 209.

Meiksins Wood, Ellen. 1998. The Retreat form Class: A New „, True” Socialism. New York: Verso.

Meiksins Wood, Ellen. 2002. The Origin of Capitalism. New York: Verso.

Meiksins Wood, Ellen. 2003. Empire of Capital. New York: Verso.

Meiksins Wood, Ellen. 2007. „A Reply to Critics". Historical Materialism 15.

Meiksins Wood, Ellen. 2008. Citizens to Lords: A Social History of Western Political Thought From Antiquity to the Middle Ages. New York: Verso.

Meiksins Wood, Ellen. 2012. Liberty and Property: A Social History of Western Political Thought from Renaissance to Enlightenment. New York: Verso.

Meiksins Wood, Ellen. 2015a. Peasant-Citizen and Slave: The Foundations of Athenian Democracy. New York: Verso. 
Meiksins Wood, Ellen. 2015b. The Pristine Culture of Capitalism: A Historical Essay on Old Regimes and Modern States. New York: Verso.

Meiksins Wood, Ellen. 2016. Democracy Against Capitalism: Renewing Historical Materialism. New York: Verso.

Mezzadra, Sandro. 2014. „Tak zwana akumulacja pierwotna.” W Marks: Nowe perspektywy, red. Libera Università Metropolitana. Tłum. Sławomir Królak. Warszawa: PWN.

Patriquin, Larry. 2012. The Ellen Meiksins Wood Reader. Leiden: Brill.

Perelman, Michael. 2004. The Invention of Capitalism: Classical Political Economy and the Secret History of Primitive Accumulation. Durham-London: Duke University Press.

Post, Charles. 2002. „Comments on the Brenner-Wood Exchange on the Low Countries". Journal of Agrarian Change 2 (1): 88-95.

Post, Charles. 2014. , The debate on Marxism and history: What is at stake? A response to Neil Davidson's »Is there anything to defend in Political Marxism?«". International Socialist Review 92.

Smith, Tony. 1999. „Brenner and Crisis Theory: Issues in Systematic and Historical Dialectics". Historical Materialism 5 (1): 145-178.

Teschke, Benno. 2011. The myth of 1648: class, geopolitics, and the making of modern international relations. London: Verso.

Thompson, Edward Palmer. 1964. The making of the English working class. New York: Pantheon Books.

Tosel, André. 2008. The Development of Marxism: Form the End of Marxism-Leninism to a Thousand Marxisms - France-Italy 1975-2005. W Criticial Companion to Contemporary Marxism, red. Jacques Bidet, Stathis Kouvelakis. Leiden: Brill. 
Eliasz Robakiewicz (1989) - doktorant w Instytucie Filozofii UW, redaktor czasopisma Praktyka Teoretyczna, redaktor i współtwórca portalu „Machina Myśli”.

\section{DANE ADRESOWE:}

Instytut Filozofii UW

Zakład Filozofii Społecznej

Krakowskie Przedmieście 3,

00-927 Warszawa

EMAIL: erobakiewicz@gmail.com

CYTOWANIE: Robakiewicz, Eliasz. 2017. „Demokracja i kapitalizm: teoria polityczna Ellen Meiksins Wood". Praktyka Teoretyczna 4 (26): 290-319

DOI: $10.14746 /$ prt.2017.4.11

\section{AUTHOR: Eliasz Robakiewicz}

TITLE: Democracy and Capitalism: Ellen Meiksins Wood's Political Theory

ABSTRACT: Ellen Meiksins Wood is the theorist who, together with Robert Brenner, created a strand of Marxism called "political Marxism," which I intend, in this article, to present to the Polish-speaking public. In the first part, I present a brief description of "political Marxism" focusing on the subject of "relations of reproduction" and on the "transition debate" (transition from feudalism to capitalism) as key problems. In the second part, I discuss how Meiksins Wood understands the concept of "class," together with her research on democracy in general and on ancient Greece in particular.

KEYWORDS: Meiksins Wood, Political Marxism, Brenner, capitalism, feudalism 